\title{
The Rule of Law à la ICTY: What the ICTY Deemed Just Good Enough and How it Supported the Countries in the Former Yugoslavia to Become Better
}

\author{
Kei Hannah Brodersen*
}

\section{Table of Contents}

A. The ICTY as a Rule of Law Promoter.................................................. 223

B. The ICTY's Shifting Rule of Law Notions Over Time ........................ 226

I. The Beginning: Standing its Ground as International Law

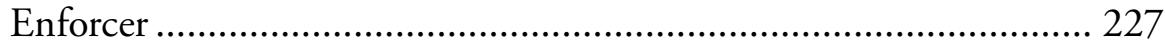

II. The Completion Strategy: Preparing the Ground for Rule of Law Promotion .................................................................229

III. The End: Preparing for the ICTY's Legacy .....................................235

C. The ICTY's Notion of the National Rule of Law............................... 236

I. Normative Dimension................................................................. 238

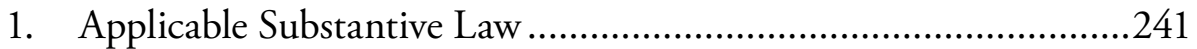

2. Human Rights .................................................................... 243

II. Institutional Dimension ......................................................... 248

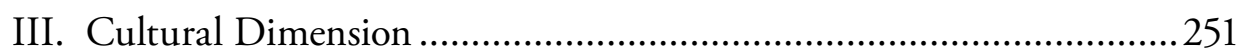

D. The ICTY's Modest Rule of Law Promotion Efforts.............................253

I. Triggering Prosecutions: Building Institutions and Transferring Cases and Material ...........................................................................2254

II. Enhancing Competence: Capacity Building ..................................259

III. Raising Awareness in order to Build a Culture of Law:

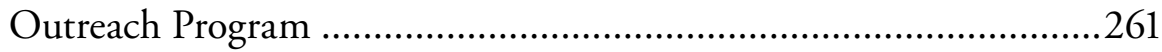

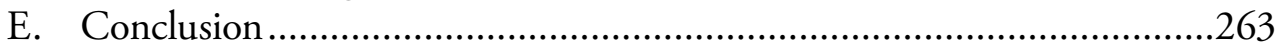

* PhD candidate, Faculty of Law, Maastricht University; the author wishes to thank the anonymous reviewers, the editors of this special issue, as well as Prof. Esther Versluis and Prof. André Klip for useful comments on earlier drafts. Special thanks also go to Dr. Paul Brodersen for improving the look of the graphs.

doi: 10.3249/1868-1581-9-1-brodersen 


\begin{abstract}
The ICTY was established as a criminal tribunal that would conduct prosecutions and trials addressing international crimes committed in the former Yugoslavia during the wars in the 1990s. Next to this core mandate, the Tribunal increasingly placed itself in the context of rule of law promotion, the trigger being its completion strategy and the insertion of Rule11bis into its Rules of Procedure and Evidence. Rule 11bis foresaw the possibility to refer cases from The Hague to national courts. In order to help prepare national justice systems for receiving these cases, the ICTY initiated a number of rule of law promotion measures, albeit without having officially defined the 'rule of law' for itself, let alone having formulated a policy for systematic rule of law promotion. Based on a comprehensive case law, discourse, and document analysis, this contribution, however, puts together a mosaic of rule of law elements recommended by the ICTY, effectively resembling a definition. This definition has a normative dimension that concerns the legislative framework of a country, an institutional dimension that prescribes rules for the functioning of its justice institutions, and a cultural dimension, requiring that the rule of law be ideologically embraced by people and State representatives. As the ICTY's rule of law promotion activities reflect what it deemed relevant in the rule of law at the respective time, it becomes clear that the Tribunal took this definition as a basis for its efforts in the countries of the former Yugoslavia. Three examples will demonstrate this. Overall, this piece contributes to understanding the legal and normative bases of the ICTY's efforts at strengthening the rule of law in post-conflict former Yugoslavia.
\end{abstract}




\section{A. The ICTY as a Rule of Law Promoter}

The International Criminal Tribunal for the former Yugoslavia (ICTY or Tribunal) was established by the United Nations Security Council in 1993 in the middle of the Balkan wars. Ever since, it has been asserted that the ICTY "instill[ed]"1, "re-establish[ed]"2, "advance[ed]"3, "enhance[d]"4, "strengthen[ed]", "improve[ed]", "shap[ed]"7, "embrace[d]", "promot[ed]" (this list could go on for pages) the rule of law in the countries under its jurisdiction. At first, these claims are surprising as promotion of the rule of law is not defined as an element of the Tribunal's mandate - neither in the legal documents regulating its work, nor in the UN Security Council resolution that founded the ICTY..$^{10}$ While in that resolution, the UN Security Council proclaimed as goals to prosecute violations of international humanitarian law, to

1 P. Akhavan, 'Justice in the Hague, Peace in the Former Yugoslavia?: A Commentary on the United Nationals War Crimes Tribunal', 20 Human Rights Quaterly (1998) 4, 737, 749 .

2 United Nations Secretary-General, The Rule of Law and Transitional Justice in Conflict and Post-Conflict Societies: Report of the Secretary-General, UN Doc S/2004/616, 3 August 2004, 13.

3 J. Hagan \& S. K. Ivković, 'War Crimes, Democracy, and the Rule of Law in Belgrade, the Former Yugoslavia, and Beyond', 605 The ANNALS of the American Academy of Political and Social Science (2006) 1, 129, 130.

4 J. Stromseth, 'Justice on the Ground: Can International Criminal Courts Strengthen Domestic Rule of Law in Post-Conflict Societies?', 1 Hague Journal on the Rule of Law (2009) 1, 87, 88.

5 ICTY, Achievements, available at http://www.icty.org/sid/324 (last visited 10 December 2018); D. F. Orentlicher, Shrinking the Space for Denial: The Impact of the ICTY in Serbia (2008), 42

$6 \quad$ P. C. McMahon \& J. L. Miller, 'From Adjudication to Aftermath: Assessing the ICTY's Goals beyond Prosecution', 13 Human Rights Review (2012) 4, 421, 422-423.

7 E. Simpson, 'Stop to the Hague: Internal versus External Factors Suppressing the Advancement of the Rule of Law in Serbia', 36 Georgetown Journal of International Law (2004) 4, 1255, 1257.

$8 \quad$ Stromseth, 'Justice on the Ground', supra note 4, 87.

$9 \quad$ L. A. Barria \& S. D. Roper, 'Judicial Capacity Building in Bosnia and Herzegovina: Understanding Legal Reform Beyond the Completion Strategy of the ICTY', 9 Human Rights Review (2008) 3, 317, 319 [Barria \& Roper, Judicial Capacity Building in Bosnia and Herzegovina].

10 Although some commentators argue that the UN Security Council hoped the ICTY would contribute to the establishment of the rule of law in the countries under its jurisdiction. See for instance: Judge Fausto Pocar in Frédéric Mégret, 'The Legacy of the ICTY as Seen through Some of Its Actors and Observers', 3 Goettingen Journal of International Law (2011) 3, 1011, 1030. 
deter future crimes, and to restore and maintain peace, ${ }^{11}$ it defined the ICTY's core competence as "to prosecute persons responsible for serious violations of international humanitarian law committed in the territory of the former Yugoslavia since 1991" in Article 1 of the Tribunal's Statute.

As time went by, however, the ICTY began to place itself in the context of rule of law promotion. At least with the adoption of the Tribunal's "completion strategy", designed to gradually wind down the Tribunal by $2010,{ }^{12}$ rule of law promotion had come to the forefront. ${ }^{13}$ ICTY representatives increasingly mentioned it as a goal, or even as a task. It is unlikely that statements to that effect were always carefully thought through, or even less, that they were based on a clear definition of the 'rule of law' or on an appreciation of how exactly the Tribunal contributed to the rule of law. Although the ICTY did take a few active and conscious steps in that regard, overall, its role in rule of law promotion was more a side-effect to its core mandate of prosecuting war criminals. As John Hocking, the last ICTY Registrar, observed with regard to the Tribunal's legacy: "I [...] see a larger impact, a spill over effect in the strengthening in the rule of law, even beyond our direct or intended efforts." 14 Hence, when reviewing individual statements about the ICTY's effect on the rule of law, it is often difficult to grasp what is meant by 'the rule of law', to what part of the rule of law the Tribunal contributes, and in what way. Upon comprehensive analysis, however, a mosaic of elements that the Tribunal associated with this term can be put together. What emerges is a framework of minimum rule of law standards

11 Cf. SC Res. 827, UN Doc S/RES/827 (1993), 25 May 1993, preamble.

12 The completion strategy foresaw a "three-phase plan", with all investigations terminated before the end of 2004, all first instance trials completed by the end of 2008 and the completion of all of the ICTY's work in 2010. The deadline concerning investigations has been met, whereas the other two have been extended several times. The Tribunal has closed in 2017. The Mechanism for International Criminal Tribunals (MICT) will subsequently complete all the remaining work, including appeals, enforcement of sentences, and non-judicial tasks.

13 Cf. ICTY, 'Completion Strategy', available at http://www.icty.org/en/sid/10016 (last visited 10 December 2018) [ICTY, Completion Strategy]; SC Res. 1503, UN Doc S/ RES/1503, 28 August 2003, 2 [SC Res. 1503]; SC Res. 1534, UN Doc S/RES/1534 (2004), 26 March 2004, 3; see also Barria \& Roper, 'Judicial Capacity Building in Bosnia and Herzegovina', supra note 9, 318; A. S. Canter, "For These Reasons, the Chamber: Denies the Prosecutor's Request for Referral": The False Hope of Rule 11Bis', 32 Fordham International Law Journal (2008) 5, 1614, 1654.

14 J. Hocking, 'Opening Remarks, Legacy Conference' (2017), 4, available at http:// www.icty.org/x/file/Press/Statements\%20and\%20Speeches/Registrar/20170622-johnhocking-opening-remarks-sarajevo_en.pdf (last visited 10 December 2018). 
with which national justice systems must comply before the ICTY deems these systems - bluntly said - good enough. ${ }^{15}$

In the following section, I will outline the policy and legal mechanisms that brought rule of law promotion into the realm of the ICTY's occupation. It will be demonstrated that the Tribunal's understanding of the rule of law has changed over time, reflecting the changing standing of the ICTY. In the beginning, the Tribunal had to struggle to be recognized as an international law enforcer - a role of which it reminded its audience again towards the end of its operation in view of building up a legacy narrative. In public statements from those times, the Tribunal therefore emphasized the international rule of law (IRoL). In between, however, the turning point being the completion strategy, its focus shifted towards the national rule of law (NRoL). With the completion strategy, the ICTY's jurisdictional regime factually changed from primacy over to complementarity to national courts. This change is manifested in Rule 11bis of the Rules of Procedure and Evidence (RPE) which were amended in 2002 in order to allow the referral of cases from The Hague to national courts. Rule 11bis triggered a number of rule of law promotion efforts by the Tribunal, effectively becoming the legal basis, or at least the legal vehicle, for the Tribunal's activities in that regard. Section C will present the ICTY's notion of the national rule of $l a w$, as it is deduced from case law, discourse, and document analysis. This notion can be divided into a normative dimension, an institutional dimension, and a cultural dimension. In the normative dimension, the necessity of a legislative framework that foresees the adjudication of international crimes and guarantees certain fundamental human rights, especially fair trial rights, is highlighted by the ICTY. This is the law that should rule. If the notion ended here, it would come down to rule by laws that foresee adjudication of international crimes under respect for fair trial rights. Yet, such a definition has no added value in practice. Hence, the ICTY identified principles that ensure or support this rule by law which can be attributed to an institutional dimension on the one hand and a cultural dimension on the other. The institutional dimension comprises independent and impartial judicial organs that work efficiently and in a transparent manner. Lastly, a culture of law is paramount to the functioning of the rule of law. According to the ICTY, ordinary citizens, as well as public officials, and representatives of the judicial sector must adopt an "ideology of

15 Necessarily, given the Tribunal's field of competence and activity, this framework remains narrow and focused on the criminal justice system, although at times, ICTY actors do adopt a broader perspective. 
legality"16 - which only happens if people are aware of accountability proceedings for international crimes and therefore develop trust into judicial institutions again. It is remarkable that also within the notion of the national rule of law one can observe change over time, with different elements being emphasized at different moments. In section $\mathrm{D}$, it will be shown through examples that the ICTY aligned its rule of law promotion efforts according to what it deemed relevant in the rule of law at the respective time. To be clear, the ICTY's main priority had always been to exercise its core mandate of prosecuting and trying perpetrators of international crimes in the courtrooms of The Hague. However, over the years, it extended its activities beyond that. With a conception of the rule of law, with which the former Yugoslav countries should comply, in mind, it took steps that were clearly geared towards supporting the domestic actors in approaching this rule of law ideal. Three main activities to that end will be presented before some concluding remarks will be made in section E.

\section{B. The ICTY's Shifting Rule of Law Notions Over Time}

In order to understand how the ICTY became an actor in rule of law promotion, it must first be understood what the Tribunal understood by the 'rule of law'. The findings of this contribution are based on a discourse analysis of all accessible public statements of ICTY representatives ${ }^{17}$ and on a content analysis of all available ICTY publications. ${ }^{18}$ In a first step, the inquiry was purely

16 T. Meron, 'Statement of Theodor Meron, President of the International Criminal Tribunal for the former Yugoslavia, Delivered at the Inauguration of the War Crimes Chamber of the State Court of Bosnia and Herzegovina', TM/MOW/945 e, 9 March 2005, available at http://www.icty.org/en/press/statement-theodor-meron-presidentinternational-criminal-tribunal-former-yugoslavia-delivered (last visited 10 December 2018) [Meron, Statement 9 March 2005].

17 Firstly, this concerned the 101 public statements and speeches given by the three ICTY officials (the ICTY presidents, chief prosecutors, and registrars), available at http://www. icty.org/en/press/statements-and-speeches-of-the-icty (last visited 10 December 2018). In addition, the opening statements of the prosecutor in every trial were considered.

18 Documents analyzed up until 21 December 2017: the Tribunal's 24 annual reports, available at http://www.icty.org/en/documents/annual-reports; 28 completion strategy reports, available at http://www.icty.org/en/documents/completion-strategy-and-mict; 2185 press releases, available at http:/www.icty.org/en/press/press-releases-archive; the 161 ICTY Digests (a publication that was distributed as of 2006 in order to inform the public about the Tribunal's work), available at http://www.icty.org/en/documents/ictydigest; as well as the only three annual reports of the Outreach Program from 2011, 2012, and 2013, available at http://www.icty.org/en/outreach/outreach-annual-reports, as well as the "15 Years of Outreach at the ICTY" report, available at http://www.icty.org/x/file/ 
quantitative; counting how many times the term 'rule of law' is mentioned in connection to the work of the Tribunal. This was done with a simple electronic search (control+F "rule of law"). In a second step, the respective hit was closely looked at in order to study 1) in what context the term 'rule of law' was used, 2) whether any precise clarification on the meaning of the term was given, or - in the absence of a definition: 3) what aspects are subsumed under the 'rule of law' or considered to be part of it. What this analysis reveals is that the ICTY's rule of law notion changed over time, reflecting the changing standing of the ICTY.

\section{The Beginning: Standing its Ground as International Law Enforcer}

In the beginning, in the years 1996-1999, the Tribunal primarily placed its work into the context of the 'international rule of law' (see figure 1 below), which refers to upholding and enforcing international law. ${ }^{19}$ One line of references to the 'rule of law' thus sounds like this excerpt from the press release that announced the commencement of the ICTY's first trial in the Tadic case:

"The upcoming trial marks the first occasion for the implementation of international humanitarian law, a body of law designed to regulate the conduct of combatants and to protect civilians during wars. It is based on standards agreed upon by States. By implementing this body of law, the International Tribunal will give it its true meaning. This first trial is thus an exercise in the assertion of the rule of law over the law of the gun, as this war-torn century draws to a close." ${ }^{20}$

In emphasizing its role as the enforcer of universal international humanitarian and criminal law, the Tribunal sought to justify its existence and operation. This was particularly necessary in its early years for several reasons: first, the ICTY was the first modern international criminal tribunal

Outreach/15-years-of-outreach/outreach-15_en_light.pdf; all last visited 10 December 2018.

19 In total, there are 55 references to the 'international rule of law' in official ICTY statements or publications, 292 to the 'national rule of law', and for 18 references it was unclear whether the international or the national rule of law was meant.

20 ICTY, 'The Tribunal's First Trial: Another Step in the Fulfillment of the Tribunal's Mandate', CC/PIO/070-E, 6 May 1996, available at http://www.icty.org/en/press/ tribunals-first-trial-another-step-fulfillment-tribunals-mandate_(last visited 10 December 2018). 
that pursued to develop upon the legacy of the Nuremberg and Tokyo tribunals that had operated five decades earlier, but with the aim of providing fair trials and of avoiding to be labelled as exercising "victor's justice". Second, the ICTY's establishment by the UN Security Council under a thereto unheard interpretation of its powers under Chapter VII of the UN Charter had been questioned, criticized, and challenged. ${ }^{21}$ In order not to be perceived as a political organ, it needed to situate itself in a legal context and recall its judicial nature. Third, as if that hadn't been challenging enough, the ICTY had a somewhat slow start that made many observers doubt whether it would ever operate effectively: it was officially established in May 1993, but without a courthouse, without staff, and without facilities. The judges, together with first staff members, who arrived in The Hague shortly after that, had to keep themselves busy with designing the Rules of Procedure and Evidence until May 1996 when the first trial against the accused Duško Tadić eventually commenced. ${ }^{22}$ In the absence of a police force that would arrest the Tribunal's defendants, the ICTY depended on States or other international organizations to arrest and surrender them. In the case of Tadić, for instance, the ICTY had ordered Germany to hand over the accused, so that it could finally start its core judicial work. Given these challenges during its first years, the ICTY pointed out the significance of its mandate - to address international crimes - which would be important enough as to heal all the criticism against it. Linking the prosecution of international crimes to the reestablishment of the international rule of law gave it the additional legitimacy that was needed to counter the criticism.

21 Most notably by its first defendant Duško Tadić: Prosecutor v. Tadić, Motion on the Jurisdiction of the Tribunal, IT-94-T, Trial Chamber, 23 June 1995, 2; for the Appeals Chamber's judgment, see: Prosecutor v. Tadić, Decision on the Defence Motion for Interlocutory Appeal on Jurisdiction, Appeals Chamber, IT-94-1-AR72, 2 October 1995, para. 9-48.

22 Cf. ICTY, 'Timeline', available at http://www.icty.org/en/features/timeline (last visited 10 December 2018). 
Time course of the total references to the IRoL and NRoL

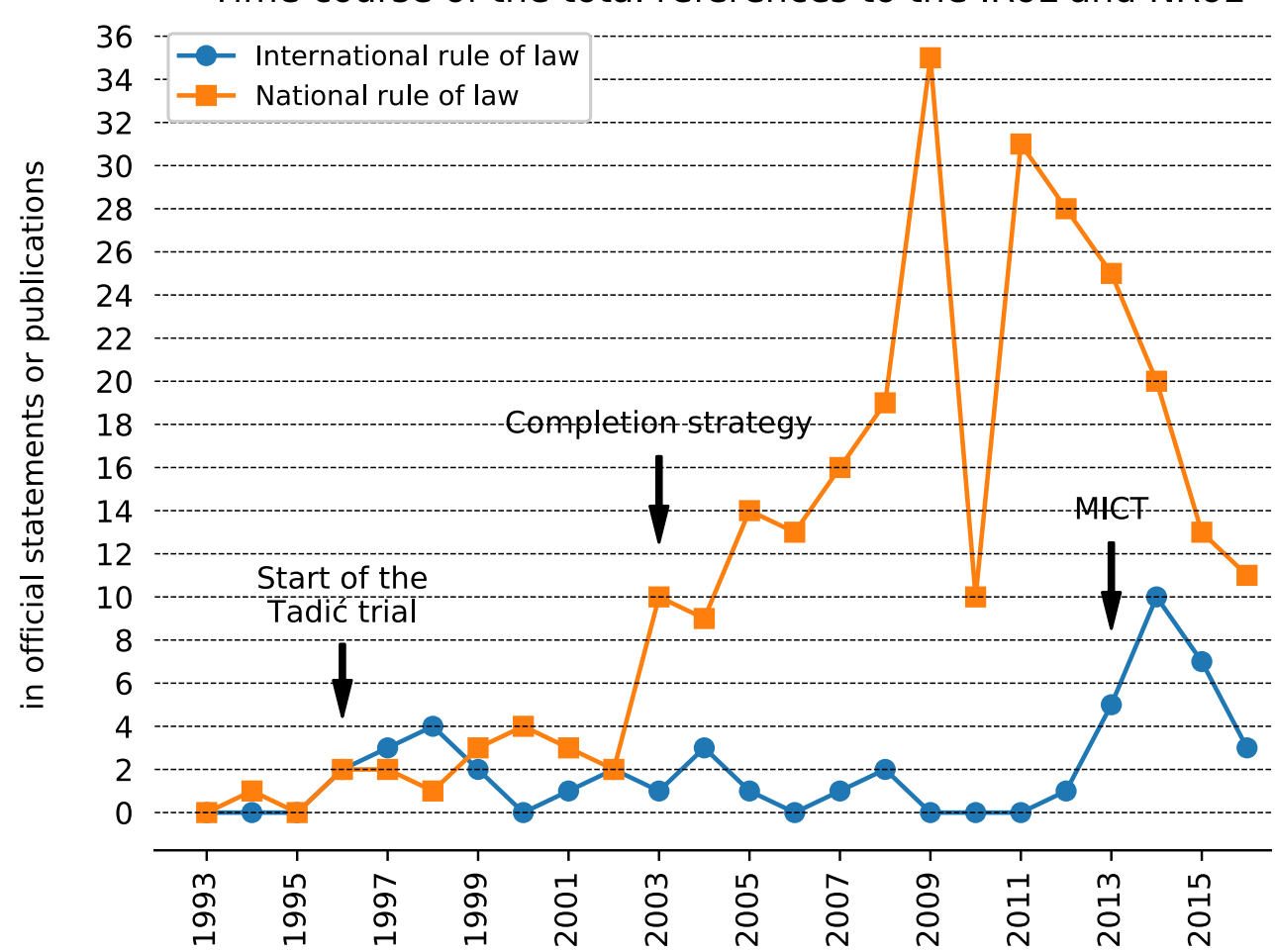

Figure 1

\section{The Completion Strategy: Preparing the Ground for Rule of Law Promotion}

Over the years, references to the NRoL, the rule of law within a country, which commonly sets out rules that govern a particular society, increased dramatically (see figure 1 above). In 2002/2003, when the ICTY was at the height of its operation, with less than 20 out of 161 indictees remaining at large, ${ }^{23}$ the ICTY judges - together with the judges of the International Criminal Tribunal for Rwanda (ICTR) - designed the completion strategy of their tribunals. The completion strategy was a plan to gradually terminate trials at the ICTY, although making sure that its work would be properly continued in the region annual_report_2003_en.pdf (last visited 10 December 2018). 
was also increasingly seen as a "key aspect" of the Tribunal's legacy. ${ }^{24}$ The idea was that the ICTY "concludes its mission successfully, in a timely way and in coordination with domestic legal systems in the former Yugoslavia." ${ }^{25}$ ICTY representatives even went as far as purporting that the Tribunal's own success depended on whether it would have rebuilt the rule of law in the countries under its jurisdiction - as expressed in the words of Serge Brammertz, the last Prosecutor of the ICTY:

"[T]he completion of the Tribunal's mandate is not the end of war crimes $^{[26]}$ justice, but the beginning of the next chapter. Further accountability for the crimes now depends fully on national judiciaries in the former Yugoslavia. Thousands of cases remain to be processed, particularly many complex cases against senior- and mid-level suspects in every country. So ultimately, I believe that the ICTY's legacy is not simply measured by our own work, but by whether the countries of the former Yugoslavia build the rule of law and demonstrate they can secure meaningful justice for the victims of serious crimes during the conflicts." ${ }^{27}$

The completion strategy report from 2009 is even more explicit in this regard as it stated that: "The ultimate goal of the Tribunal's legacy strategy is entrenchment of the rule of law in the former Yugoslavia." ${ }^{28}$

In this spirit, the UN Security Council had already explicitly called upon the Tribunal to "strengthen[...] the capacity of [the national] jurisdictions" 29

24 Cf. C. Garbett, 'Transitional Justice and "National Ownership": An Assessment of the Institutional Development of the War Crimes Chamber of Bosnia and Herzegovina', 13 Human Rights Review (2012) 1, 65, 65.

25 ICTY, 'Completion Strategy', supra note 13; cf. SC Res. 1503, supra note 13, 2.

26 This generic term is used to refer to the prosecution of all so-called international crimes (namely, those commonly found in the statutes of international criminal courts and tribunals). It will also sometimes be used in this contribution and will - unless made explicit otherwise - be synonymous with "international crimes".

27 ICTY, '\#ICTY24: Commemoration held at United Nations Headquarters' (2017), available at http:/www.icty.org/en/press/icty24-commemoration-held-at-united-nationsheadquarters (last visited 10 December 2018).

28 ICTY, Completion Strategy Report November 2009, UN Doc S/2009/589, 13 November 2009, 21, available at http://www.icty.org/x/file/About/Reports\%20and\%20Publications/ CompletionStrategy/completion_strategy_13nov2009_en.pdf (last visted 12 June 2018) [ICTY, Completion Strategy Report November 2009].

29 SC Res. 1503, supra note 13, 2. 
in the former Yugoslavia when it endorsed the proposed completion strategy in 2003 , as this was considered "crucially important to the rule of law" ${ }^{30}$. At that same time, the political and legal systems in the former Yugoslav countries were consolidating, with Bosnia and Herzegovina $(\mathrm{BiH})$ becoming a member of the Council of Europe in April 2002 and Serbia in April 2003. ${ }^{31}$ The Tribunal more and more assumed the role of assisting this consolidation process, especially by contributing to rebuilding their national justice systems.

As one of the major instruments of the completion strategy, the ICTY judges proposed to transform Rule 11bis of the Rules of Procedure and Evidence into a legal basis for transferring cases to national courts in the former Yugoslavia. ${ }^{32}$ Essentially, this case transfer system would be killing two birds with one stone: it would permit the ICTY to reduce its case load in view of winding down, and it would kick off and catalyze domestic war crimes proceedings, thereby strengthening the domestic rule of law. As will be shown in section $\mathrm{D}$ below, the case transfers brought about a series of rule of law promotion measures, effectively rendering Rule 11bis the mechanism behind the ICTY's rule of law transfer efforts.

The idea was to transfer cases concerning low- and intermediate-level perpetrators from the ICTY to national courts in the former Yugoslavia, and to concentrate on those crimes "most prejudicial to international public order" 33

30 Ibid., 2; the same was reiterated in operative part point 9 of SC Res. 1534, UN Doc S/ RES/1534 (2004), 26 March 2004, 3.

31 Available at https://www.coe.int/en/web/portal/bosnia-and-herzegovina (last visited 10 December 2018) and available at https:/www.coe.int/en/web/portal/serbia (last visited 10 December 2018); Croatia had been a member since November 1996; available at https:/www.coe.int/en/web/portal/croatia (last visited 10 December 2018).

32 Rule 11bis had been inserted into the ICTY's RPE as early as 1997, at the time providing the possibility to suspend an indictment at the ICTY if a national court could and would exercise its jurisdiction; Rule 11 bis in its original available at http:/www.icty.org/x/ file/Legal\%20Library/Rules_procedure_evidence/IT032_rev12_en.pdf (last visited 10 December 2018) [Rule 11bis]. For amendments, see the different versions available at http://www.icty.org/en/documents/rules-procedure-evidence (last visited 10 December 2018); and generally M. Bohlander, 'Referring an indictment from the ICTY and ICTR to another court - Rule 11bis and the consequences for the law of extradition', 55 International and Comparative Law Quarterly (2006) 1, 219. Its current form was introduced in July 2004 with revision 32.

33 C. Jorda, 'Report on the Judicial Status of the International Criminal Tribunal for the former Yugoslavia and the Prospects for Referring Certain Cases to National Courts', annexed to the 'Letter dated 10 June 2002 from the President of the International Criminal Tribunal for the former Yugoslavia addressed to the Secretary General', annexed to the 'Letter dated 17 June 2002 from the Secretary-General addressed to 
in The Hague. A case would, however, only be referred if certain conditions were satisfied, most importantly, that the national court would be able to fully conform with internationally recognized standards of human rights and due process. $^{34}$

Rule 11bis, amended accordingly in December 2002, foresaw the possibility to refer a case (whether with or without the accused already being arrested) to any State which could and would exercise jurisdiction over it: ${ }^{35}$ either because the crimes had been committed on its territory (Rule 11bis (A) (i) RPE), or because the accused was arrested in that State (Rule 11bis (A) (ii) RPE), or because the State otherwise has jurisdiction and accepts the case (Rule 11bis (A) (iii) RPE). ${ }^{36}$ A case could only be referred if the State's justice system was adequately prepared, if the accused would receive a fair trial, and if the death penalty would not be imposed or carried out. ${ }^{37}$ Importantly, although the condition of the State being "adequately prepared" is mentioned only in Rule 11bis (A) (iii) and on a plain reading, one would therefore think that this condition only relates to those States otherwise having jurisdiction, it must in fact be met for any (of the three) jurisdictional scenarios. This follows from the system of Rule 11bis that requires reading paragraphs (A) and (B) together. The Appeals Chamber has held this view in Stanković:

"as a strictly textual matter, Rule 11 bis $(\mathrm{A})$ does not require that a jurisdiction be 'willing and adequately prepared to accept' a transferred case if it was the territory in which the crime was committed or in which the accused was arrested. But that is beside the point, because unquestionably a jurisdiction's willingness and capacity to accept a referred case is an explicit prerequisite for any referral to a domestic jurisdiction [...]. Thus, the 'willing and

the President of the Security Council' , 19 June 2002, 5, available at http://www.icty. org/x/file/About/Reports\%20and\%20Publications/CompletionStrategy/judicial_status_ report_june2002_en.pdf (last visited 10 December 2018) [Jorda, Report on the Judicial Status of the ICTY].

34 Cf. ibid., 13-14.

35 A Referral Bench can decide to refer a case either proprio motu or upon application of the prosecutor (R11bis (B) RPE), supra note 32.

36 In the beginning, the amendments only comprised States that would have territorial jurisdiction, or where the accused would be arrested, but this was extended in July 2004. R11bis (A)RPE, supra note 32.

37 R11bis (B)RPE, supra note 32. 
adequately prepared' prong of Rule 11bis(A)(iii) is implicit also in the Rule 11bis(B) analysis." ${ }^{38}$

Apart from that, because high profile cases were to remain in The Hague, the Referral Bench also had to consider the gravity of the crimes at stake and the level of responsibility of the accused. ${ }^{39}$ When a decision for referral of a case was taken, the accused, together with all necessary material supporting the indictment had to be transferred to the competent national authorities. ${ }^{40}$

An important element of Rule 11bis was the possibility for the ICTY Prosecutor to monitor the national proceedings. ${ }^{41}$ If s/he deemed it necessary for instance because of insufficient respect for fair trial rights $-s /$ he could apply to the Referral Bench to revoke the referral. ${ }^{42}$ This deferral mechanism was supposed to encourage national judiciaries to do particularly well in complying with international standards and to threaten them in case they would not. ${ }^{43}$ A deferral would have meant for the national justice system to lose face both, towards their own population as well as towards the 'international community' a situation, which all countries of the former Yugoslavia wanted to avoid in order to rehabilitate their reputation as solid democracies operating under the rule of law. So, it was in the interest of both the ICTY and the national authorities to establish the conditions for a fair handling of these so-called Rule 11bis cases. ${ }^{44}$

38 Prosecutor v. Stanković, Decision, Appeals Chamber, IT-96-23/2-PT, 1 September 2005, para. 40.

39 R11bis (C) RPE, supra note 32; paragraphs (A) and (B) also set out procedural safeguards that must be met before referral is permitted: a case can only be referred back to the national judiciary if an indictment had been issued and confirmed already, but the trial must not yet have begun. The accused must have had the opportunity to be heard.

$40 \quad$ R11bis (D) (i) and (iii) RPE, supra note 32.

$41 \quad$ R11bis (D) (iv) RPE, supra note 32.

42 R11bis (F) RPE, supra note 32.

43 In the words of former chief prosecutor Carla del Ponte: "The mere existence of such a provision [that would enable the ICTY to defer back the case] should act as a strong incentive for the relevant domestic judicial authorities to handle the case in accordance with accepted international standards."; ICTY OTP, Completion Strategy Report May 2004, UN Doc S/2004/420, 24 May 2004, 45, available at http://www.icty. org/x/file/About/Reports\%20and\%20Publications/CompletionStrategy/completion_ strategy_24may2004_en.pdf (last visited 10 December 2018).

44 Cf. ICTY OTP, Completion Strategy Report November 2017, UN Doc S/2017/1001, 29 November 2017, 76, available at http://www.icty.org/x/file/About/Reports\%20and\%20 Publications/CompletionStrategy/171129-completion-strategy-report-icty.pdf (last visited 10 December 2018); indeed, the State Court of Bosnia and Herzegovina sees the referral of six cases to its jurisdiction as a "recognition" of its professionality and its 
At the same time, monitoring the adjudication of Rule 11bis cases provided the opportunity for targeted capacity building as it directly revealed deficiencies in the prosecution and adjudication of war crimes trials. Those deficiencies would then be addressed in tailor-made trainings for the local actors involved. ${ }^{45}$ That way, "[t]he referral of [Rule 11bis] cases to national jurisdictions also served [...] to strengthen the capacity of those jurisdictions in the prosecution and trial of violations of international humanitarian law," 66 "thus reinforcing the rule of law in these new States. ${ }^{\prime \prime 7}$ The monitoring was implemented by the Organisation for Security and Co-operation in Europe (OSCE) on behalf of the ICTY Office of

compliance with high standards in adjudicating war crimes: "Priznanje profesionalnog rada $i$ poštivanje visokih standarda u krivičnim procesima pred Sudom BiH ogleda se i u odlukama Medunarodnog krivičnog suda za bivšu Jugoslaviju, koji je, u skladu sa Pravilom 11 bis, Sudu BiH na dalje postupanje ustupio 6 predmeta sa 10 osumnjičenih. To su bile prve odluke o ustupanju predmeta jednom sudu u regionu, što je za Sud BiH bilo veliko priznanje." (in English: "The recognition that the SCBiH works professionally and respects high standards in its criminal trials is reflected in the decisions of the ICTY to refer six cases concerning ten accused to be adjudicated at the $\mathrm{SCBiH}$. Those were the first decisions to transfer cases to a court in the region, which represents for the $\mathrm{SCBiH}$ a huge appreciation." (author's own translation)); Sud Bosne i Herzegovine, 'Istorijat Suda BiH', available at http://www.sudbih.gov.ba/stranica/86/pregled (last visited 10 December 2018).

45 Interview with representatives of the OSCE, Sarajevo, 2 February 2017; similar: ICTY OTP, Completion Strategy Report May 2007, UN Doc S/2007/283, 16 May 2007, 16, available at http://www.icty.org/x/file/About/Reports\%20and\%20Publications/ CompletionStrategy/completion_strategy_16may2007_en.pdf (last visited 10 December 2018)

46 ICTY, Completion Strategy Report November 2011, UN Doc S/2011/716, 16 November 2011, 13, available at http://www.icty.org/x/file/About/Reports\%20and\%20Publications/ CompletionStrategy/completion_strategy_16nov2011_en.pdf (last visited 10 December 2018).

47 ICTY, Completion Strategy Report May 2012, UN Doc S/2012/354, 23 May 2012, 11, available at http://www.icty.org/x/file/About/Reports\%20and\%20Publications/ CompletionStrategy/completion_strategy_23may2012_en.pdf (last visited 10 December 2018); see also ICTY, Completion Strategy Report November 2004, UN Doc S/2004/897, 23 November 2004, 3, available at http://www.icty.org/x/file/About/Reports\%20and\%20 Publications/CompletionStrategy/completion_strategy_23november2004_en.pdf (last visited 10 December 2018); ICTY, Completion Strategy Report May 2005, UN Doc S/2005/343, 25 May 2005, 3, available at http://www.icty.org/x/file/About/Reports\%20 and\%20Publications/CompletionStrategy/completion_strategy_25may2005_en.pdf (last visited 10 December 2018) [ICTY, Completion Strategy Report May 2005]. 
the Prosecutor (OTP), ${ }^{48}$ and the capacity building programme was developed in close cooperation between the two organizations.

Strikingly, the completion strategy de facto changed the Tribunal's jurisdictional regime from primacy and deferrals, to complementarity and referrals. Article 9 of the ICTY Statute stipulates a concurrent jurisdictional regime between the Hague Tribunal and domestic courts, with the Tribunal retaining primacy. This implies that the ICTY was never meant to prosecute all persons responsible for serious violations committed in the territory of the former Yugoslavia. In fact, when proposing to establish the ICTY, the UN Secretary General suggested that instead of precluding and preventing national courts to exercise their jurisdiction, they should be encouraged to prosecute and try perpetrators of violations of their national law. ${ }^{49}$ For about a decade, this did not have any implications. Instead of advocating national prosecutions, the ICTY Prosecutor applied for deferrals under Article 9 (2) of the ICTY Statute and as a consequence, a number of cases for international crimes were taken away from national courts and deferred to the Tribunal in The Hague. ${ }^{50}$ However, with the implementation of the completion strategy and the introduction of Rule 11bis, this trend was not only stopped, but reversed. As of then, the Tribunal gave back cases and it would only step in when they were not handled correctly at the domestic level. At the same time, the ICTY assisted domestic jurisdictions in living up to its standards through a broad capacity building programme.

Thus, while the completion strategy heralded the Tribunal's policy change regarding its jurisdictional regime, putting the national rule of law into the focus of the Tribunal, Rule 11bis became the vehicle for the ICTY's rule of law promotion efforts.

\section{The End: Preparing for the ICTY's Legacy}

Interestingly, as the Tribunal's closure approached and with the Mechanism for International Criminal Tribunals (MICT), the court that carries out the remaining functions of the ICTR and the ICTY since their respective

48 For the agreement and OSCE progress reports on each case, see ICTY, 'Status of Transferred Cases', available at http://www.icty.org/en/cases/transfer-of-cases/status-oftransferred-cases (last visited 10 December 2018). See also ICTY, Completion Strategy Report May 2005, supra note 47, 10.

49 Cf. United Nations Secretary-General, Report of the Secretary General Pursuant to Paragraph 2 of Security Council Resolution 808, UN Doc S/25704, 3 May 1993, 16.

50 The most famous deferrals are the cases against the ICTY's first accused Duško Tadić, which was taken from Germany, and against Dražan Erdemović, taken from Yugoslavia. 
closures in 2015 and 2017, preparing to operate as of 2013, allusions to the international rule of law became more prominent again (see figure 1 above). In public statements, ICTY officials again more often reminded its audience of its role as an international law enforcement mechanism and recalled its achievements in that respect, as exemplified by former ICTY President Meron observing in 2015 that "through hundreds of rulings addressing principles of international criminal, humanitarian, and human rights law, the ICTY has played a crucial role in strengthening international law and the rule of law and has made major contributions to the implementation of the purposes of the UN Charter." ${ }^{\prime 1}$ It thereby sought to make sure that its pioneering role in upholding the international rule of law wouldn't be forgotten.

In the remaining sections of this contribution, references to the international rule of law will be disregarded as it falls outside the scope of rule of law transfer and the focus will be on the 'national rule of law' and the ICTY's promotion efforts.

\section{The ICTY's Notion of the National Rule of Law}

Clues about the Tribunal's national rule of law notion can be found in the jurisprudence rendered following referral applications by the OTP under Rule $11 b i{ }^{52}$ A system good enough for receiving a case would necessarily abide by the rule of law. Taken together, the factors the Referral Bench examined before agreeing to refer a case, ${ }^{53}$ constitute a framework of minimum standards with which national justice systems must comply before the Tribunal deemed

51 Adding that, in the years to come, the MICT (of which Meron is the current President) will carry forward the important work of the ICTY and the ICTR, thereby reflecting "the UN's continued commitment to justice and principled accountability”; ICTY, 'Tribunal and the Mechanism Commemorate 70 years of the United Nations', Press Release 20 October 2015, available at http:/www.icty.org/en/press/tribunal-and-mechanismcommemorate-70-years-united-nations (last visited 10 December 2018).

52 Necessarily, given the Tribunal's field of competence and activity, this framework remains narrow and focused on the criminal justice system, although at times, ICTY actors do adopt a broader perspective.

53 It might be worth noting that the Referral Bench was the same in all cases, consisting of Judge Alphons Orie (presiding), Judge O-Gon Kwon, and Judge Kevin Parker. The composition of the Appeals Chamber varied, however always involving the judges Fausto Pocar, Theodor Meron, Mohamed Shahabuddeen, Mehmet Güney, Wolfgang Schomburg, Florence Ndepele Mwachande Mumba, Andrésia Vaz, and Liu Daqun. 
them "adequate". ${ }^{4}$ This framework can be complemented through the discourse and document analysis of official statements and publications, deducing further elements that the ICTY views as being part of the national rule of law, or that it clearly links to the national rule of law. The list of elements is presented in figure 2 below; and the emerging mosaic, with its normative dimension, institutional dimension, and cultural dimension will be presented in the remainder of this section. It is remarkable that also within the notion of the national rule of law one can observe change over time, with different elements being emphasized at different moments. In section $\mathrm{D}$, three main rule of law promotion activities, reflecting the Tribunal's current rule of law notion at the respective time, will be presented.

54 Necessarily, this framework remains fragmented: the general scope is determined by Rule 11bis (supra note 32) itself, which mentions some of the parameters to be appraised. What elements within these broad parameters the Bench specifically examines or what elements it analyses in depth depends on the questions at stake in each individual case, and often also on what the parties emphasize in their submissions. Consequently, the framework that emerges is more detailed on some elements (such as on impartiality and independence of national courts, the right to examine witnesses or humane detention conditions; see below) than on others. For instance, safeguards that an accused does not have to stand trial if s/he is mentally unfit (as part of the accused's fair trial rights) were only addressed in Kovačević, as this was not an issue in any other case. 


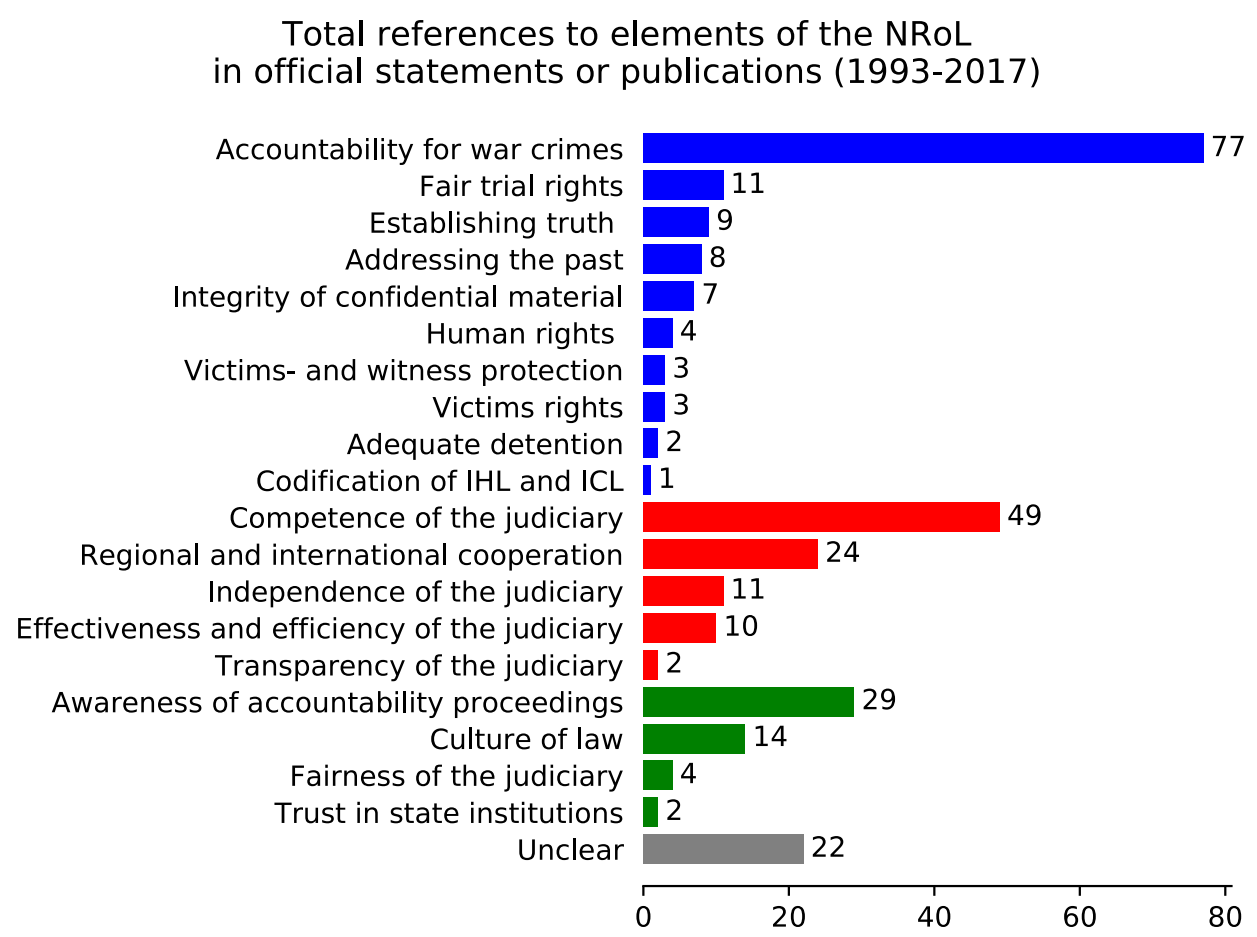

Figure 2

Normative dimension (blue): accountability for war crimes, fair trial rights, establishing truth, addressing the past, integrity of confidential material, human rights, victims-and witness protection, victims rights, adequate detention, codification of IHL and ICL; institutional dimension (red): competence of the judiciary, regional and international cooperation, independence of the judiciary, effectiveness and efficiency of the judiciary, transparency of the judiciary; cultural dimension (green): awareness of accountability proceedings, culture of law, fairness of the judiciary, trust in state institutions;" unclear": references to the national rule of law without any connection to a particular element, or where the reference is ambiguous

\section{Normative Dimension}

According to the ICTY, in order for the societies in the countries of the former Yugoslavia to function under the rule of law, they need to 
acknowledge the past, ${ }^{55}$ learn from it, reconcile with it, and move on. ${ }^{56}$ In this context, it is necessary that international crimes are addressed through criminal prosecutions. Perpetrators must be arrested, ${ }^{57}$ brought to justice, ${ }^{58}$ held accountable, ${ }^{59}$ and punished. ${ }^{60}$ On the one hand, trials would help to establish

55 Cf. ICTY, 'Completion Strategy: Prosecutor Brammertz's Address Before the Security Council', Press Release, FS/OTP/1466e, 7 December 2011, available at http://www. icty.org/en/press/completion-strategy-prosecutor-brammertz's-address-security-council (last visited 10 December 2018); this and subsequent references to different rule of law elements are only examples. As has been explained, many references are repeated many times and it would be excessive to replicate all of them in the footnotes.

56 Cf. C. del Ponte, 'Address by Tribunal Prosecutor Carla Del Ponte to NATO Parliamentary Assembly: The ICTY and the Legacy of the Past', CdP/OTP/ PR1193e, 26 October 2007, available at http://www.icty.org/en/press/address-tribunal-prosecutor-carla-del-pontenato-parliamentary-assembly-belgrade-icty-and (last visited 10 December 2018); in the figures, these elements have been regrouped together under "addressing the past".

57 Cf. G. Kirk McDonald, 'ICTY President Gabrielle Kirk McDonald addresses the “Dayton” Peace Implementation Council', CC/PIO/272-E, 9 December 1997, available at http://www.icty.org/en/press/icty-president-gabrielle-kirk-mcdonald-addressesdayton-peace-implementation-council (last visited 10 December 2018); C. del Ponte, 'Address by Carla del Ponte, Prosecutor of the ICTY, to the UN Security Council', CDP/P.I.S./917-e, 23 November 2004, available at http://www.icty.org/en/press/addresscarla-del-ponte-prosecutor-icty-un-security-council (last visited 10 December 2018); S. Brammertz, 'Completion Strategy Report: Prosecutor Brammertz's address before the Security Council', VE/CS/PR1571e, 12 June 2013, available at http:/www.icty.org/en/ press/completion-strategy-report-prosecutor-brammertz's-address-security-council-0 (last visited 10 December 2018).

58 Cf. F. Pocar, 'Address of Judge Fausto Pocar, President of the International Criminal Tribunal for the Former Yugoslavia, to the United Nations General Assembly', AH/ MOW/1288e, 13 October 2008, available at http://www.icty.org/en/press/address-judgefausto-pocar-president-international-criminal-tribunal-former-yugoslavia-united (last visited 10 December 2018).

59 Cf. T. Meron, 'Statement by President Meron on the occasion of International Justice Day', 16 July 2015, 1, available at http://www.icty.org/x/file/Press/Statements\%20and\%20 Speeches/President/150716-president_meron_international_justice_day_en.pdf (last visited 10 December 2018); G. Kirk McDonald, 'The International Criminal Tribunal for the former Yugoslavia: Making a Difference or Making Excuses?', JL/PIU/402-E, 13 May 1999, available at http://www.icty.org/en/press/international-criminal-tribunalformer-yugoslavia-making-difference-or-making-excuses (last visited 10 December 2018) [Kirk McDonald, Making a Difference or Making Excuses?].

60 Cf. ICTY, Annual Report 1994, UN Doc A/49/342 S/1994/1007, 29 August 1994, 12, available at http://www.icty.org/x/file/About/Reports\%20and\%20Publications/ AnnualReports/annual_report_1994_en.pdf (last visited 10 December 2018); in the figures, these elements have been regrouped together under "accountability for war crimes". 
the facts about the violent past. ${ }^{61}$ Moreover and more importantly, however, they are about establishing individual criminal responsibility. ${ }^{62}$ Prosecuting and trying perpetrators of international crimes was reiterated over and over again throughout the existence of the Tribunal, with a noticeable high in the beginning of the 2000s. In that period, the ICTY started to envisage its own closure and therefore pointed out that prosecutions of international crimes would have to be continued by the national justice systems in the former Yugoslavia (see figure 3 below). Accordingly, it started to lobby and support these countries, especially Bosnia and Herzegovina, to set up specialized institutions for that purpose. It also helped to kick off the work of these institutions by referring them low- and mid-level perpetrator cases, and scrutinizing and supporting the adjudication of these cases. This explicit rule of law promotion effort will be further explained in section D.I. below. The importance of accountability proceedings in order to reestablish the rule of law was again frequently recalled when the ICTY approached its closure, of which it was reminded when the MICT was preparing to operate and in its very final year of existence (see figure 3 below).

61 Cf. ICTY, Digest 52, 17 February 2009, 1, available at http://www.icty.org/x/file/About/ Reports\%20and\%20Publications/ICTYDigest/icty_digest_52_en.pdf (last visited 10 December 2018); in the figures, this element is called "establishing truth".

62 Cf. Prosecutor v. Deronjić, Closing Statement, IT-02-61-S, 231, available at http://www. icty.org/x/cases/deronjic/trans/en/040128IT.htm (last visited 10 December 2018). 
Time course of the most frequently referenced elements of the normative dimension of the NRoL

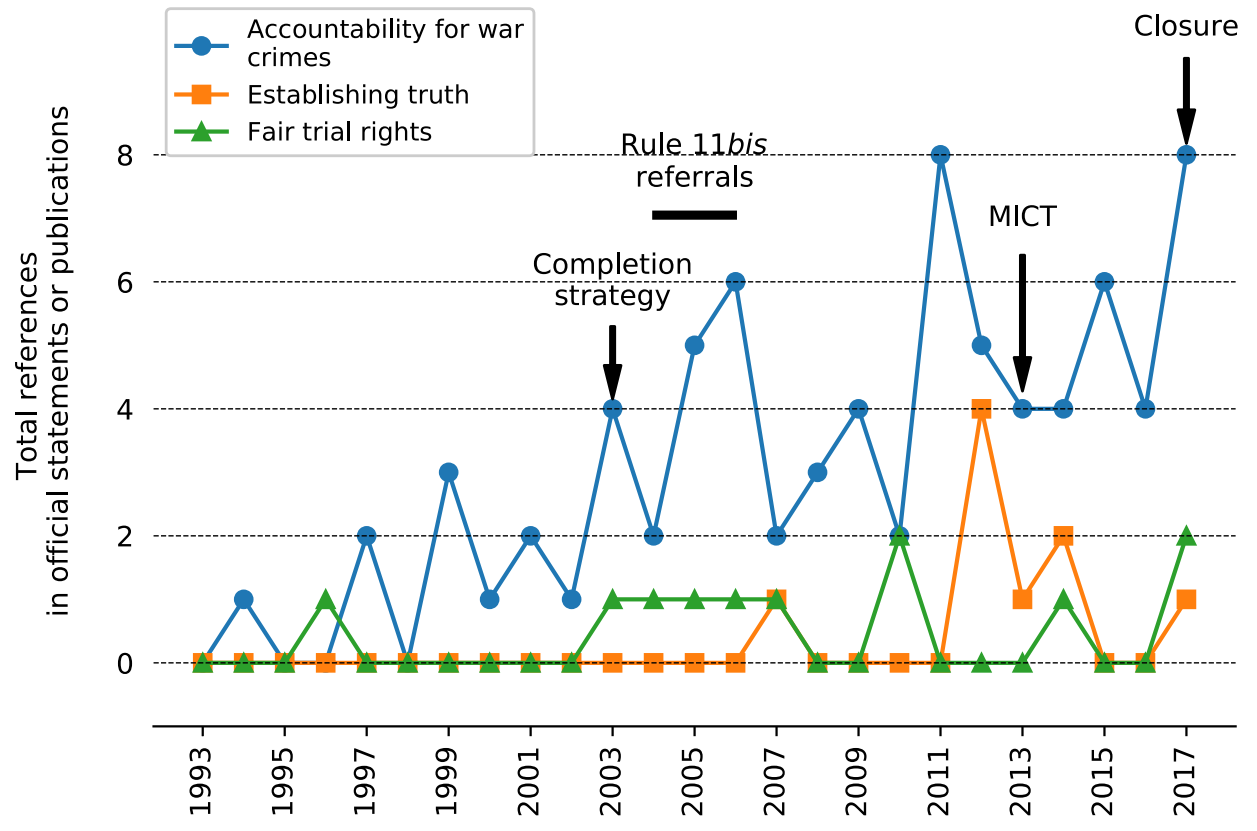

Figure 3

\section{Applicable Substantive Law}

The legal framework within which prosecutions and trials should be conducted was clarified in Rule 11bis cases, where the Tribunal verified whether the domestic law is adequate for prosecuting, trying, and eventually (if found guilty) punishing the defendant. ${ }^{63}$ In general, the ICTY deemed that in order to hold international crimes trials, ${ }^{64}$ the domestic legal framework must entail

63 Cf. Prosecutor v. Stanković, Decision, Referral Bench, IT-96-23/2-PT, 17 May 2005, para. 37 [Cf. Prosecutor v. Stanković, Referral Bench]; see also W. W. Burke-White, 'The Domestic Influence of International Criminal Tribunals: The International Criminal Tribunal for the Former Yugoslavia and the Creation of the State Court of Bosnia \& Herzegovina', 46 Columbia Journal of Transnational Law (2007) 2, 279, 323 [BurkeWhite, The Domestic Influence].

64 Cf. ICTY, 'OHR-ICTY Working Group on Development of BiH Capacity for Warcrimes Trial Successfully Completed', Press Release, OHR/P.I.S./731e, 21 February 2013, available at http://www.icty.org/en/press/ohr-icty-working-group-developmentbih-capacity-war-crimes-trial-successfully-completed (last visited 10 December 2018); T. Meron, 'Statement by President Meron on Establishment of Special War Crimes Chamber 
provisions of international humanitarian and international criminal law. ${ }^{65}$ This would be an "assertion of the rule of law over the law of the gun" "66 "breaking the cycle of impunity" ${ }^{\prime 67}$. The Referral Bench's focus, however, was whether the material elements of the crime are covered by the criminal law applicable at the time of the offence, ${ }^{68}$ whether it provides for appropriate modes of liability to reflect the accused's conduct, and whether an appropriate punishment exists. ${ }^{69}$

Although the ICTY thus recommended codifying international criminal law, it was satisfied if the material elements of offences underlying international crimes were covered by the applicable ordinary criminal law. ${ }^{70}$ It was important,

in Bosnian State Court', JL/P.I.S./761-e, 13 June 2003, available at http://www.icty.org/ en/press/statement-president-meron-establishment-special-war-crimes-chamber-bosnianstate-court (last visited 10 December 2018); T. Meron, 'Address of Judge Theodor Meron, President of the ICTY, to the UN Security Council', TM/P.I.S./916-e, 23 November 2004, available at http://www.icty.org/en/press/address-judge-theodor-meron-presidenticty-un-security-council (last visited 10 December 2018); ICTY, Annual Report 2005, UN Doc A/60/267-S/2005/532, 17 August 2005, 38, available at http:/www.icty.org/x/ file/About/Reports\%20and\%20Publications/AnnualReports/annual_report_2005_ en.pdf (last visited 10 December 2018).

65 Cf. ICTY, Completion Strategy Report November 2009, supra note 28, 21; in the figures, this element is called "codification of IHL and ICL".

66 ICTY, 'The Tribunal's First Trial: Another Step in the Fulfillment of the Tribunal's Mandate', Press Release, CC/PIO/070-E, 6 May 1996, available at http://www.icty.org/ en/press/tribunals-first-trial-another-step-fulfillment-tribunals-mandate (last visited 10 December 2018).

67 G. Kirk McDonald, 'Address to the United Nations General Assembly by Judge Gabrielle Kirk McDonald, President of the International Criminal Tribunal for the former Yugoslavia', JL/P.I.S./445-E, 8 November 1999, available at http://www.icty.org/en/ press/address-united-nations-general-assembly-judge-gabrielle-kirk-mcdonald-presidentinternational (last visited 10 December 2018).

68 Cf. Prosecutor v. Stanković, Referral Bench, supra note 63, para. 46.

69 Cf. ibid., para. 32. The exact same wording is also used in Prosecutor v. Rašević and Todović, Decision, Referral Bench, IT-97-25/1-PT, 8 July 2005, para. 34 [Prosecutor $v$. Rašević and Todović, Referral Bench]; Prosecutor v. Mejakić, Gruban, Fuštar, Knežević, Decision, Referral Bench, IT-02-65-PT, 20 July 2005, para. 43 [Prosecutor v. Mejakić, et al., Referral Bench]; Prosecutor v. Janković, Decision, Referral Bench, IT-96-23/2-PT, 22 July 2005, para. 27 [Prosecutor v. Janković, Referral Bench]; Prosecutor v. Ljubičić, Decision, Referral Bench, IT-00-41-PT, 12 April 2006, para. 31 [Prosecutor v. Ljubičić, Referral Bench]; Prosecutor v. Kovačević, Decision, Referral Bench, IT-01-42/2-I, 17 November 2006, para. 25 [Prosecutor v. Kovačević, Referral Bench]; Prosecutor v. Milan Lukić and Sredoje Lukić, Decision, Referral Bench, IT-98-32/1-PT, 5 April 2007, para. 45 [Prosecutor v. Milan Lukić and Sredoje Lukić, Referral Bench].

70 Focus on the conduct means that it is not necessarily required that a particular offence is conceptualized as an international crime. It is sufficient that the conduct is covered by the 
however, that the legality principle, especially its components nullum crimen-and nulla poena sine lege were respected and that no one was convicted or punished upon law that was not applicable at the time of the offence. ${ }^{71}$

In addition, the ICTY underlined the importance to have those modes of liability available that most accurately mirror the respective responsibility of accused in international crimes trials. ${ }^{72}$ Most prominently, this concerned the notion of command responsibility as established in Article 7 (3) ICTY Statute. ${ }^{73}$

Lastly, it was necessary that an appropriate punishment was available. For international crimes trials, appropriate punishment would often entail a prison sentence, ${ }^{74}$ but the Tribunal did not specify the proper length of sentences. Also concerning sanctions, the ICTY welcomed that the legality principle is cherished, this time the principle of lex mitior (that in the case of changes in the laws between the commission of the offence and its adjudication, the law that is more lenient to the accused shall be applied). It should, however, not impede the trial and punishment of a defendant. ${ }^{75}$

\section{Human Rights}

Publicly, the ICTY has always maintained that human rights need to be ensured at the domestic level. ${ }^{76}$ Although this referred to all human rights as enshrined in the European Convention on Human Rights (ECHR) (including those that are not directly linked to prosecutions of international crimes, such as freedom of expression $)^{77}$, the focus naturally was on whether the criminal

law, whether as an ordinary crime or as an international crime.

71 Cf. Prosecutor v. Janković, Referral Bench, supra note 69, para. 40-41; Prosecutor v. Milan

Lukic and Sredoje Lukić, Referral Bench, supra note 69, para. 55.

72 Cf. Jorda, 'Report on the Judicial Status of the ICTY', supra note 33, 19.

73 Cf. Prosecutor v. Kovačević, Referral Bench, supra note 69, para. 43-47; Prosecutor v. Rašević and Todović, Referral Bench, supra note 69, para. 51; Prosecutor v. Ljubičić, Referral Bench, supra note 69, para. 34-35.

74 Cf. Prosecutor v. Stanković, Referral Bench, supra note 63, para. 40 and 43.

75 Cf. Prosecutor v. Milan Lukić and Sredoje Lukić, Referral Bench, supra note 69, para. 55.

76 Cf. T. Meron, 'Address of Judge Theodor Meron, President of the ICTY, to the UN General Assembly', JP/ P.I.S/912-e, 15 November 2004, available at http://www.icty. org/en/press/address-judge-theodor-meron-president-icty-un-general-assembly-15november-2004 (last visited 10 December 2018); T. Meron, 'Statement by President Meron on the occasion of International Justice Day', 16 July 2015, available at http:// www.icty.org/en/press/statement-president-meron-occasion-international-justice-day (last visited 10 December 2018); in the figures, this element is called "human rights".

77 Cf. G. Krik McDonald, 'Statement by Judge Mcdonald, President of the International Criminal Tribunal for the Former Yugoslavia', JL/PIU/359-E, 5 November 1998, available 
procedural law of a country would be human rights conform. ${ }^{78}$ An evaluation of whether the human rights of the defendant are respected if a case is handed over to the national level has occupied a prominent place in all referral cases, and in the time period of referrals, the Tribunal frequently recalled the importance of respecting fair trial rights (see figure 3 above). In Rule 11bis case law, different aspects were emphasized, depending on the specific characteristics of the case. Most importantly, the Tribunal needed to be assured that the accused would not face the death penalty and that $s /$ he would receive a fair trial ${ }^{79}-$ but also that national law provided for decent detention conditions. In that respect, the Tribunal welcomed accession to the ECHR and the International Covenant on Civil and Political Rights (ICCPR) as this would constitute an additional layer of protection of fair trial rights, next to possible national constitutional law provisions or safeguards provided for in national criminal law. ${ }^{80}$ Lastly, the ICTY stressed that the domestic legal framework must ensure victims and witness support and protection, ${ }^{81}$ as well as the integrity of confidential materials. ${ }^{82}$

In Stanković, the Referral Bench laid out a list of minimum fair trial rights which largely replicated Article 21 ICTY Statute - which in itself is a reproduction of fair trial rights as recognized by Article 14 ICCPR from 1966 and by Article 6 of the ECHR. ${ }^{83}$

at http://www.icty.org/en/press/statement-judge-mcdonald-president-internationalcriminal-tribunal-former-yugoslavia (last visited 10 December 2018).

78 In the figures, this element is called "fair trial rights".

79 This is required by Rule 11 bis (B), supra note 32.

80 Cf. Prosecutor v. Mejakić, et al., Referral Bench, supra note 69, para. 69 and 79; Prosecutor v. Milan Lukić and Sredoje Lukić, Referral Bench, supra note 69, para. 74.

81 In the figures, this element is called "victims- and witness protection", and "victims rights" when statements refer to their right to compensation.

82 Cf. ICTY, 'Vojislav Šešelj Charged with Contempt of Court', Press Release. NJ/ MOW/1300e, 22 January 2009, available at http://www.icty.org/en/press/vojislav-šešeljcharged-contempt-court (last visited 10 December 2018); ICTY, Completion Strategy Report November 2007, UN Doc S/2007/663, 12 November 2007, 10, available at http:// www.icty.org/x/file/About/Reports\%20and\%20Publications/CompletionStrategy/ completion_strategy_12november2007_en.pdf (last visited 10 December 2018) [ICTY, Completion Strategy Report November 2007]; in the figures, this element is called "integrity of confidential material".

83 Cf. Prosecutor v. Stanković, Referral Bench, supra note 63, para. 55; this list was reiterated in Prosecutor v. Kovačević, Referral Bench, supra note 69, para. 68; Prosecutor v. Rašević and Savo Todović, Referral Bench, supra note 69, para. 72; Prosecutor v. Mejakić, et al., Referral Bench, supra note 69, para. 68; Prosecutor v. Janković, Referral Bench, supra note 69, para. 62; Prosecutor v. Milan Lukić and Sredoje Lukić, Referral Bench, supra note 69, para. 71. 
Firstly, all persons are equal before the court. ${ }^{84}$ In the Balkan context, this especially referred to equality regardless of ethnic or religious background. ${ }^{85}$ Secondly, everyone is entitled to a fair and public hearing by a competent, independent and impartial tribunal established by law. ${ }^{86}$ This not only signifies that due process standards must be respected,${ }^{87}$ but also that several institutional safeguards need to be provided in order to in fact ensure a fair trial. ${ }^{88}$ The third right entails the presumption of innocence until proven guilty according to the law. ${ }^{89}$ Fourthly, the accused has the right to be informed promptly and in detail in a language which s/he understands of the nature and cause of the charge against him..$^{90}$ During trial, the accused has the right to free assistance of an interpreter if s/he cannot understand or speak the language used in the proceedings. ${ }^{91}$

Fifthly, the accused's right to a defense comprises different elements that the Tribunal distinguished but that are somewhat related: first, it contains the right of an accused to have adequate time and facilities for the preparation of his/her defense and to communicate with counsel of his/her own choosing; second, the right to be tried in his/her presence, and to defend him/herself in person or through legal assistance of his own choosing; and third, the right to be informed, if s/he does not have legal assistance, of this right, and to have legal assistance assigned to him/her, in any case where the interests of justice so require, and without payment by him/her in any such case if s/he does not Srpska', Press Release, CC/PIO/101-E, 31 July 1996, available at http://www.icty.org/ en/press/joint-press-statement-visit-hague-delegation-republika-srpska (last visited 10 December 2018).

86 Cf. Prosecutor v. Stanković, Referral Bench, supra note 63, para. 55; ICTY, 'Trial Chamber II Hands Down its Decision on the Subpoena Issue: The Subpoena Duces Tecum Issued to Croatia and its Defence Minister in January 1997 Must be Complied with by 18 August 1997', Press Release, CC/PIO/230-E, 18 July 1997, available at http://www.icty. org/en/press/trial-chamber-ii-hands-down-its-decision-subpoena-issue-subpoena-ducestecum-issued-croatia (last visited 10 December 2018) [ICTY, Press Release 18 July 1997]; Burke-White, 'The Domestic Influence', supra note 63, 323.

87 Cf. T. Meron, 'Address of Judge Theodor Meron, President of the ICTY, to the UN Security Council', TM/P.I.S./916-e, 23 November 2004, available at http://www.icty. org/en/press/address-judge-theodor-meron-president-icty-un-security-council (last visited 10 December 2018).

88 This will be elaborated further down under "Institutional Dimension".

89 Cf. Prosecutor v. Stanković, Referral Bench, supra note 63, para. 55.

90 Cf. ibid.

91 Cf. ibid. 
have sufficient means to pay for it. ${ }^{92}$ It is accepted by the ICTY that the right to counsel of one's own choosing is not without limitation: it extends only to counsel who are entitled to appear before the respective court of trial and the accused must make his/her choice accordingly. In addition, it is also acceptable that in case the accused cannot pay for the counsel, s/he may choose from a list of available defense counsel - and if s/he doesn't, a counsel will be appointed by the court. ${ }^{33}$

The sixth fair trial right, the right to an expeditious trial, ${ }^{94}$ grants the accused the right to be tried without undue delay. ${ }^{95}$ Any possible delay in proceedings must not be undue, unreasonable or unnecessary. ${ }^{96}$ It is accepted that a system that grants an accused the right to be brought before the court in the shortest reasonable time period and to be tried without delay and that requires that the duration of custody is reduced to the shortest time necessary, is in accordance with the right to an expeditious trial. In addition, it was lauded if incentives exist under the law to proceed without undue delay. ${ }^{97}$

Seventhly, an accused has the right to examine, or have examined, the witnesses against him and to obtain the attendance and examination of witnesses on his behalf under the same conditions as witnesses against him. ${ }^{8}$ The Referral Bench indirectly related the issue of witness protection to the right of the accused to examine witnesses, as it may "promot[e] witness presence at trial by providing assurance to witnesses that legal measures exist for their protection." 99 Measures provided for in the laws of Bosnia and Herzegovina were deemed sufficient in this respect: in criminal proceedings, both parties may request an order for protective measures, such as anonymity of a witness or the use of a pseudonym both, inside and outside of court. The Witness Protection Programme Law of Bosnia and Herzegovina regulates possible measures to take outside the courtroom,

92 Cf. ibid.

93 Cf. Prosecutor v. Rašević and Todović, Referral Bench, supra note 69, para. 88; Prosecutor v. Mejakić, et al., Referral Bench, supra note 69, para. 111; Prosecutor v. Janković, Referral Bench, supra note 69, para. 77.

94 Cf. ICTY, Press Release 18 July 1997, supra note 86.

95 Cf. Prosecutor v. Stanković, Referral Bench, supra note 63, para. 55; ICTY, Annual Report 2012, A/67/214-S/2012/592, 1 August 2012, 17, available at http://www.icty.org/x/file/ About/Reports\%20and\%20Publications/AnnualReports/annual_report_2012_en.pdf (last visited 10 December 2018).

96 Cf. Prosecutor v. Stanković, Referral Bench, supra note 63, para. 77.

97 Cf. Prosecutor v. Rašević and Todović, Referral Bench, supra note 69, paras. 96, 102.

98 Cf. Prosecutor v. Stanković, Referral Bench, supra note 63, para. 55.

$99 \quad$ Ibid., para. 89. 
such as change of identity or issuance of cover documents. ${ }^{100}$ Likewise, the Serbian Law on Protection of Participants in Criminal Proceedings - which is applicable to witnesses - provides for a protection program which can apply measures including physical protection of persons and property, change of place of residence, or the concealing or change of identity. ${ }^{101}$ This was also conceived as sufficient. ${ }^{102}$ While ICTY representatives repeatedly recalled the necessity of adequate victim and witness protection, the Appeals Chamber acknowledged in Jankovic ${ }^{103}$ that "no judicial system, be it national or international, can guarantee absolute witness protection." 104 At the same time, the protection of witnesses can be somewhat detrimental to the right of the accused to properly defend him/herself as s/he might need to know who is testifying against him/her. In this respect, the Referral Bench welcomed certain safeguards so that "a proper balance will be struck between the rights of an accused and the need to protect vulnerable witnesses and witnesses under threat." 105 Thus, the application of protective measures must be carefully considered beforehand and only ordered after taking into account the views of the defense, and "sufficient details" should be released to the accused for him/her to prepare his/her defense. ${ }^{106}$ In addition, in any case, the accused must be in the position to examine the protected witness by asking questions. ${ }^{107}$

As the eighth right enshrines the right not to incriminate oneself, the accused shall not be compelled to testify against him/herself or to confess guilt. ${ }^{108}$

Lastly, and although not mentioned in Article 21 ICTY Statute or in the list of fair trial rights the Referral Bench had reiterated since Stanković, the right not to stand trial in case of physical or mental unfitness was examined as a "fair trial consideration[...]"109 in Kovačević. ${ }^{110}$

According to Rule 11bis (B), a case could only be referred if the death penalty would not be imposed or carried out. Case law has clarified that through the ratification of Protocol 13 of ECHR, which abolished the death penalty in

Cf. ibid.; Prosecutor v. Mejakić, et al., Referral Bench, supra note 69, paras. 105, 106.

Cf. Prosecutor v. Kovačević, Referral Bench, supra note 69, para. 84.

Cf. ibid., para. 86.

And reiterated Prosecutor v. Rašević and Todović, Referral Bench, supra note 69, para. 65.

Prosecutor v. Janković, Referral Bench, supra note 69, para. 49.

Prosecutor v. Rašević and Todović, Referral Bench, supra note 69, para. 91.

Cf. Prosecutor v. Mejakic, et al., Referral Bench, supra note 69, para. 100.

Cf. ibid., para. 101.

Cf. Prosecutor v. Stanković, Referral Bench, supra note 63, para. 55.

Prosecutor v. Kovačević, Referral Bench, supra note 69, para. 50.

Cf. ibid. 
all circumstances, this condition is fulfilled. That holds true even if national law applicable at the time of the offence foresaw the death penalty as punishment, since Protocol 13 would nonetheless preclude its imposition. ${ }^{111}$

In addition to these rights, the ICTY held that adequate detention "touches upon the fairness of [a] jurisdiction's criminal justice system." 112 There must be decent detention facilities for remand and convicted persons, ${ }^{113}$ where their rights are respected by those responsible for detention pre-trial, during trial, and post-trial, ${ }^{114}$ and where detainees are treated equally, no matter their nationality, political views, or religious beliefs. ${ }^{115}$ Also the length of detention during pre-trial and trial periods must be adequate. ${ }^{116}$

\section{Institutional Dimension}

Clearly, the ICTY's focus within the normative dimension of the rule of law is that a legislative framework exists that enables the prosecution and processing of international crimes, while effectively ensuring human rights, especially fair trial rights. However, as mentioned, this is not enough. The rule of law is only guaranteed if institutions exist that are capable of carrying out such proceedings. For that, in the ICTY's view, judicial institutions must be independent ${ }^{117}$ and impartial, and - most importantly - legal practitioners, including judges, prosecutors, support staff, and defense counsel must be welltrained and competent. ${ }^{118}$ These elements have been stressed a lot as of the moment that referrals of cases from the ICTY to the national judiciaries of the

111 Cf. Prosecutor v. Stanković, Referral Bench, supra note 63, para. 55; Prosecutor v. Rašević and Todović, Referral Bench, supra note 69, para. 56; Prosecutorv. Mejakić, et al., Referral Bench, supra note 69, para. 66, 67; Prosecutor v. Janković, Referral Bench, supra note 69, paras. 47, 48; Prosecutor v. Ljubičić, Referral Bench, supra note 69, paras. 38, 39; Prosecutor v. Milan Lukić and Sredoje Lukić, Referral Bench, supra note 69, para. 62.

112 Prosecutor $v$. Stankovic, Appeals Chamber, supra note 38, para. 34; in the figures, this element is called "adequate detention".

113 Cf ICTY, Prosecutor v. Janković, Appeals Chamber, Decision, IT-96-23/2-PT, 15 November 2005, paras. 69-76 [ICTY, Prosecutor v. Janković, Appeals Chamber]; ICTY, Completion Strategy Report November 2007, supra note 82, 11.

114 Cf. Prosecutor v. Janković, Appeals Chamber, supra note 113, paras. 69-76.

115 Cf. Jorda, 'Report on the Judicial Status of the ICTY', supra note 33, 25.

116 Cf. Prosecutor v. Mejakić, et al., Referral Bench, supra note 69, para. 109; that the law of Bosnia and Herzegovina provided that the maximum period of pre-trial and trial detention does not exceed 1.5 years was mentioned as particularly suspect- and accusedfriendly.

117 In the figures, this element is called "independence of the judiciary".

118 In the figures, this element is called "competence of the judiciary". 
former Yugoslavia became a possibility (see figure 4 below). ${ }^{119}$ Of course, these countries needed to be prepared to process these cases, and at the ICTY, one was most preoccupied due to possible lacks of independence and competence of the national judiciaries. In reaction, in an endeavor to support the national judiciaries (especially in Bosnia and Herzegovina, Croatia, and Serbia) which all had set up specialized institutions for the prosecution and trial of international crimes, and whose work had been kicked off with the referred Rule 11bis cases, the ICTY engaged in enhanced capacity building, in particular between 2005 and 2011. This rule of law promotion effort will be further presented in section D.II. below.

Time course of the most frequently referenced elements of the institutional dimension of the NRoL

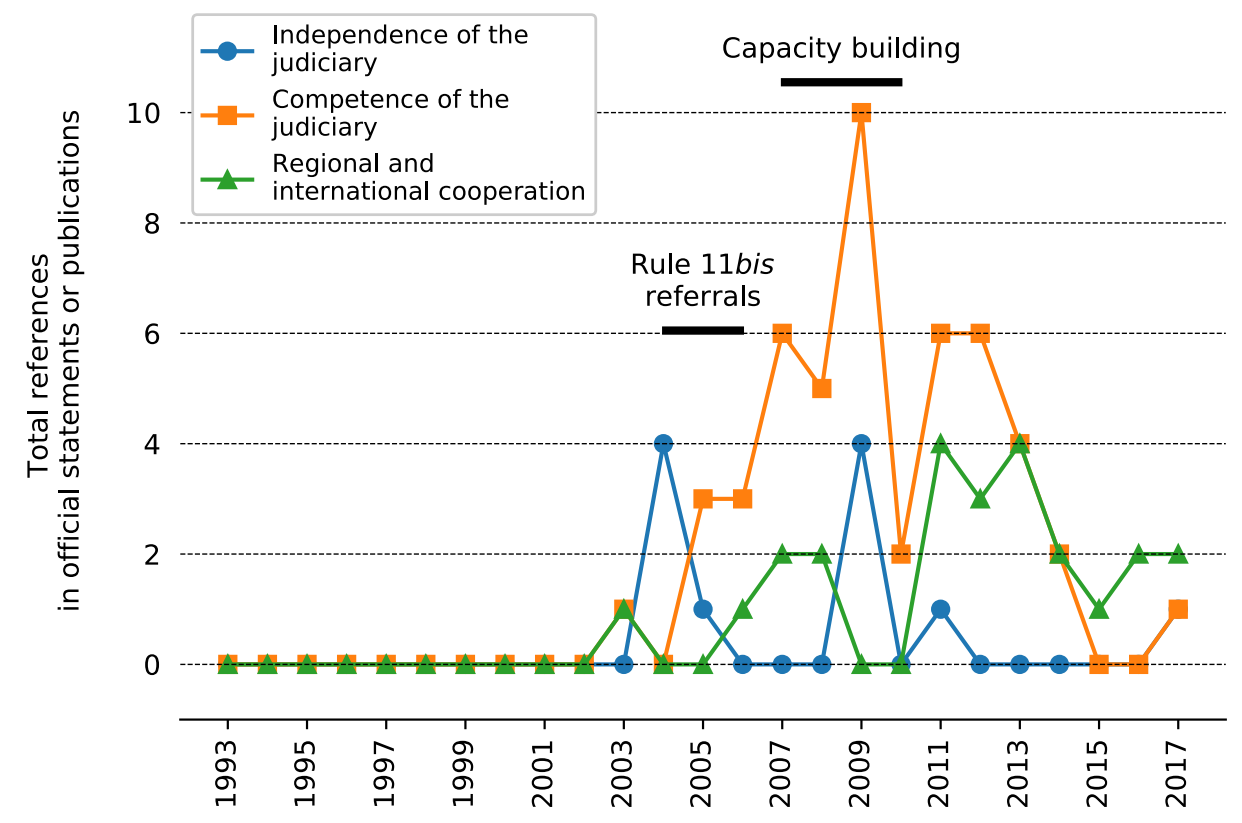

Figure 4

For the Tribunal, independence of a judicial system ${ }^{120}$ first and foremost refers to the absence of anything that is not judicial, but political: the system as

119 As explained, this was first envisaged within the completion strategy in 2003.

120 Cf. Prosecutor v. Stanković, Referral Bench, supra note 63, para. 55; ICTY, Press Release 18 July 1997, supra note 86; ICTY, Digest 58, 2, available at http:/www.icty.org/x/ file/About/Reports\%20and\%20Publications/ICTYDigest/icty_digest_58_en.pdf (last 
such must not be politicized, ${ }^{121}$ political authorities should not be able to interfere in investigations, ${ }^{122}$ and trials should not be used for political purposes, ${ }^{123}$ or "pleas[e] political pressure" 124 .

A judicial system, especially courts, also need to be impartial. Although impartiality has not directly been defined by the Tribunal, it entails several principles: firstly, in order to ensure the integrity of judges, i.e. that they are not corrupt, they must be "sufficiently remunerated and their independence guaranteed." 125 Secondly, a balanced composition of courts, particularly in ethnic terms, is helpful. ${ }^{126}$ Impartiality heavily depends on appropriate selection standards and procedures for judicial personnel, ${ }^{127}$ and on the availability of possibilities to disqualify a judge for lack of impartiality. ${ }^{128}$

Next to independence and impartiality, the ICTY also repeatedly highlighted judicial transparency, ${ }^{129}$ efficiency and effectiveness, ${ }^{130}$ and competence ${ }^{131}$ as principles within the intuitional dimension of the rule of law. To

visited at 10 December 2018); ICTY, Annual Report 2009, A/64/205-S/2009/394, 31 July 2009, 8, para. 16, available at http://www.icty.org/x/file/About/Reports\%20and\%20 Publications/AnnualReports/annual_report_2009_en.pdf (last visited 10 December 2018); ICTY, 'Paddy Ashdown and Carla Del Ponte Call for BiH Parliament to Make War Crimes Chamber Operational by January 2005', Press Release, FH/P.I.S./903-e, 20 October 2004, available at http://www.icty.org/en/press/paddy-ashdown-and-carladel-ponte-call-bih-parliament-make-war-crimes-chamber-operational (last visited 10 December 2018).

121 Cf. Jorda, 'Report on the Judicial Status of the ICTY', supra note 33, 19.

122 Cf. ibid., 25.

123 Cf. ICTY, Completion Strategy Report November 2004, supra note 47, 3.

124 ICTY, Completion Strategy Report May 2008, S/2008/326, 14 May 2008, 11, available at http://www.icty.org/x/file/About/Reports\%20and\%20Publications/ CompletionStrategy/completion_strategy_14may2008_en.pdf (last visited 10 December 2018).

125 Jorda, 'Report on the Judicial Status of the ICTY', supra note 33, 25, fn. 24.

126 Cf. Jorda, ibid., 19.

127 Cf. Prosecutor v. Stanković, Referral Bench, supra note 63, paras. 27-30; Prosecutor v. Janković, Appeals Chamber, supra note 113, para. 53.

128 Cf. Prosecutor v. Mejakić, et al., Referral Bench, supra note 69, para. 86.

129 Cf. ICTY, Digest 63, 14 September 2009, 1, available at http://www.icty.org/x/file/About/ Reports\%20and\%20Publications/ICTYDigest/icty_digest_63_en.pdf (last visited 10 December 2018); in the figures, this element is called "transparency of the judiciary".

130 Cf. ICTY, Completion Strategy Report November 2007, supra note 82, 10; in the figures, this element is called "effectiveness and efficiency".

131 Cf. Jorda, 'Report on the Judicial Status of the ICTY', supra note 33, 19; ICTY, Digest 52, supra note 61, 1; ICTY, Completion Strategy Report November 2009, supra note 28, 21; Burke-White, 'The Domestic Influence', supra note 63, 323. 
ensure efficiency, sufficient financial and logistical resources are paramount. ${ }^{132}$ To ensure effectiveness, the Tribunal demanded international and regional judicial cooperation, ${ }^{133}$ which requires not only an adequate legal framework for the transfer of suspects and accused, evidence, or proceedings, but also compliance with relevant request. ${ }^{134}$ Lastly, to ensure competence, members of the justice system need to be well selected and well trained in conducting the relevant investigations and judicial proceedings, ${ }^{135}$ including war crimes proceedings. ${ }^{136}$

\section{Cultural Dimension}

Apart from principles that relate to the functioning of the institutional set-up of a national justice system, a legal culture is indispensable for the rule of law to be properly anchored in a society. A "culture of law instead of violence"137, and an "ideology of legality"138 should govern societies. This relates to everyone, including ordinary citizens. But the ICTY of course also stressed the particular necessity for justice institutions that "entrench the rule of law" 139 and that are an http://www.icty.org/x/file/About/Reports\%20and\%20Publications/AnnualReports/ annual_report_2011_en.pdf (last visited 10 December 2018); in the figures, this element is called "regional and international cooperation".

134 Cf. ICTY OTP, Completion Strategy Report May 2012, S/2012/354, 23 May 2012, 34, available at http://www.icty.org/x/file/About/Reports\%20and\%20Publications/ CompletionStrategy/completion_strategy_23may2012_en.pdf (last visited 10 December 2018).

135 Cf. Jorda, 'Report on the Judicial Status of the ICTY', supra note 33, 19; ICTY, Completion Strategy Report November 2009, supra note 28, 21; Burke-White, 'The Domestic Influence', supra note 63, 323.

Cf. ICTY, Completion Strategy Report May 2014, S/2014/351, 16 May 2014, 7, available at http://www.icty.org/x/file/About/Reports\%20and\%20Publications/ CompletionStrategy/completion_strategy_16may2014_en.pdf (last visited 10 December 2018); ICTY, Press Release 21 February 2013, supra note 64; ICTY, Annual Report 2005, supra note 64, 38.

137 C. del Ponte, 'Address by the Prosecutor of the International Criminal Tribunals for the former Yugoslavia and Rwanda, Mrs. Carla del Ponte, to the United Nations Security Council', JJJ/P.I.S./709-e, 30 October 2002, available at http://www.icty.org/en/press/ address-prosecutor-international-criminal-tribunals-former-yugoslavia-and-rwanda-mrscarla-del (last visited 10 December 2018).

138 Meron, 'Statement 9 March 2005', supra note 16.

139 ICTY, 'Tribunal President Welcomes Support for Bosnia and Herzegovina's Judicial Institutions', Press Release, CVO/MO/1059e, 31 March 2006, available at http://www. 
"articulation of shared values and moral imperatives"140.141 Thus, State organs, especially judicial institutions need to work in a fair ${ }^{142}$ manner and treat everyone equally, regardless of their ethnic or religious background. ${ }^{143}$

In order for citizens to develop faith in State institutions, ${ }^{144}$ respect for the judicial process, ${ }^{145}$ and trust in "judicial accountability" $146,{ }^{147}$ they need to be properly informed about the work of criminal justice institutions, ${ }^{148}$ especially about international criminal proceedings that address a country's violent past. ${ }^{149}$ The ICTY called for raising such awareness in the region, especially towards the end of its existence (see figure 5 below). But it also sought to contribute to it through its own outreach program, which was massively professionalized as of 2009. This particular rule of law promotion effort will be further elaborated upon in section D.III. below.

icty.org/en/press/tribunal-president-welcomes-support-bosnia-and-herzegovinas-judicialinstitutions (last visited 10 December 2018).

T. Meron, 'Address to the U.N. Security Council', 5 June 2014, 2, available at http://www. icty.org/x/file/Press/Statements\%20and\%20Speeches/President/140605_president_ meron_un_sc_en.pdf (last visited 10 December 2018).

141 In the figures, these elements have been grouped together under "culture of law".

142 Cf. G. Kirk McDonald, Prosecutor v. Tadić, Opening Statements, IT-94-1-T, 9, available at http://www.icty.org/x/cases/tadic/trans/en/960507IT.htm (last visited 10 December 2018); Meron, 'Address to the U.N. Security Council', supra note 140, 2.

143 Cf. ICTY, Press Release 31 July 1996, supra note 85; in the figures, these elements have been grouped together under "fairness of the judiciary".

144 Cf. Kirk McDonald, 'Making a Difference or Making Excuses?', supra note 59.

145 Cf. S. Brammertz, 'Statement of the ICTY Prosecutor Serge Brammertz in Relation to the Gotovina and Markac Appeal Judgement', 21 November 2012, 1, available at http://www.icty.org/x/file/Press/Statements\%20and\%20Speeches/Prosecutor/121121_ prosecutor_brammertz_en.pdf (last visited 10 December 2018).

146 S. Brammertz, 'Address of Mr. Serge Brammertz, Prosecutor International Criminal Tribunal for the Former Yugoslavia and Mechanism for International Criminal Tribunals to the United Nations Security Council', 8 December 2016, 3, available at http://www. icty.org/x/file/Press/Statements\%20and\%20Speeches/Prosecutor/161208_prosecutor_ brammertz_un_sc_en.pdf (last visited 10 December 2018).

147 In the figures, these elements have been grouped together under "trust in state institutions".

148 Cf. ICTY, Completion Strategy Report November 2009, supra note 28, 21.

149 Cf. ICTY, 'Support from European Union to the ICTY', Press Release, LM/P.I.S./547-e, 7 December 2000, available at http://www.icty.org/en/press/support-european-unionicty (last visited 10 December 2018); in the figures, these elements have been grouped together under "awareness of accountability proceedings". 
Time course of the most frequently referenced elements of the cultural dimension of the NRoL

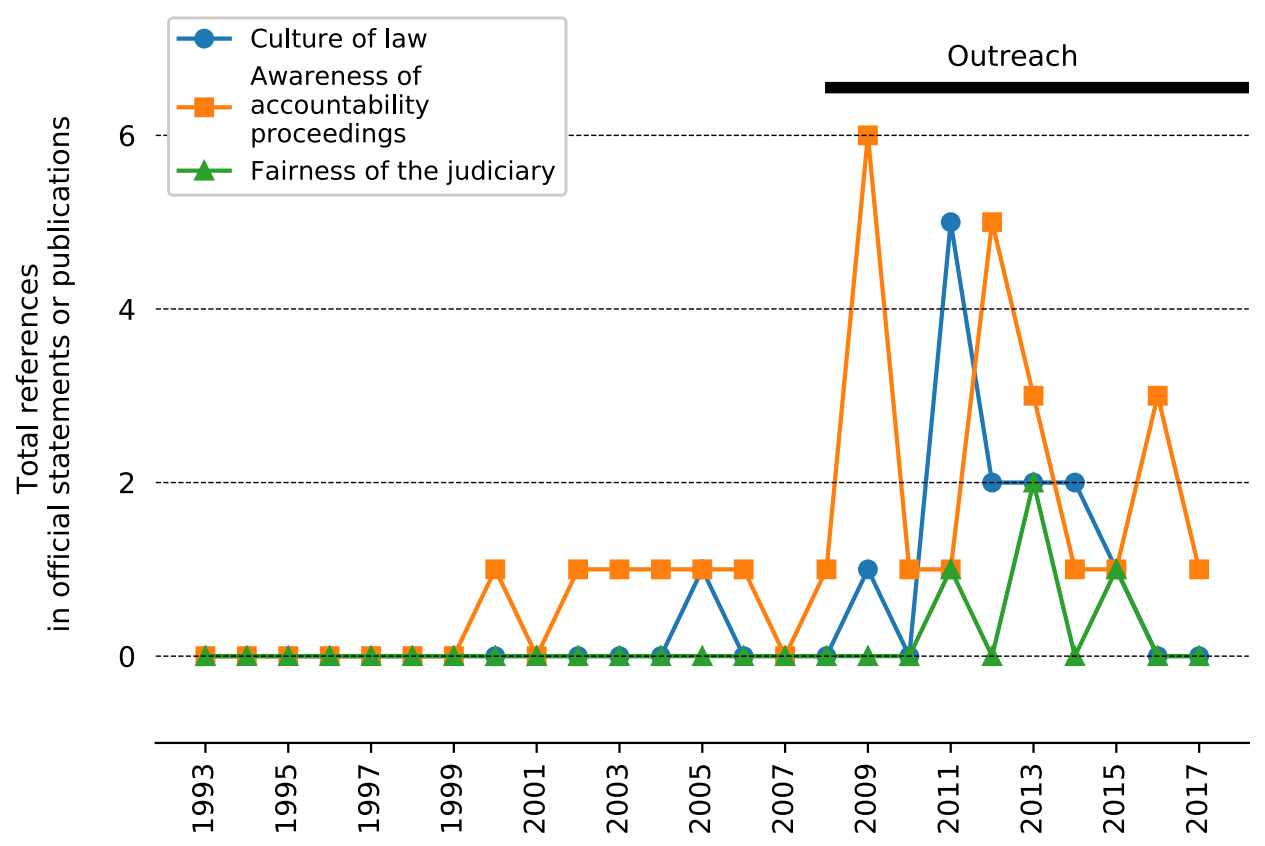

Figure 5

\section{The ICTY's Modest Rule of Law Promotion Efforts}

Although the ICTY is a criminal court with the main purpose of prosecuting and trying perpetrators of international crimes, the Tribunal clearly saw its own work in a broader - rule of law enhancing - context. Representatives frequently claimed that the Tribunal contributed to the rule of law, either to the international rule of law through its role of enforcer of international humanitarian and criminal law, or to the national rule of law. When analyzing official statements and publications of the ICTY, one gets a grip on what is meant by the national rule of law, although no official definition exists. At least with the adoption of the completion strategy and insertion of Rule 11bis into the ICTY Rules of Procedure and Evidence, it is obvious that the Tribunal undertook steps to enhance the national rule of law in the countries under its jurisdiction. While Rule 11bis did not require the ICTY to make an active effort (rather, the burden to comply with the rule's conditions for case referral is on the national justice systems), its existence nevertheless triggered a broad range of rule of law promotion activities, all geared towards preparing the national 
systems to meet the required standards. By virtue of Rule 11bis the Tribunal assumed the role of the rule of law promoter in the region.

Although the initiatives were many, the three main ones will be briefly sketched out here: ${ }^{150}$ triggering national prosecutions and proceedings of international crimes, enhancing competence of national judiciaries, and raising awareness in order to build a culture of law. They directly relate to those elements that appear most frequently within each rule of law dimension (in the normative dimension, this element was conducting accountability proceedings for international crimes; in the institutional dimension, it was competence of the judiciary; and in the cultural dimension, this was awareness of accountability proceedings that address a country's violent past) in official statements or publications. Therefore, while Rule 11bis was the legal trigger for the ICTY to engage in rule of law promotion, the notion of the national law it gradually developed informed the exact rule of law promotion steps to take.

\section{Triggering Prosecutions: Building Institutions and Transferring Cases and Material}

With the UN Security Council's call to strengthen the domestic justice systems in mind, the completion strategy and in particular, Rule 11bis prompted one of the most significant ICTY rule of law promotion initiatives: in order to trigger prosecutions in the region, the Tribunal lobbied the former Yugoslav countries to establish specialized institutions to prosecute and try perpetrators of international crimes, and advised them in this endeavor. The advantage of specialized institutions is mostly that they permit to concentrate resources and expertise, ${ }^{151}$ which is particularly necessary in the context of adjudicating international crimes. These trials are complex, both in terms of the underlying substantive law and in terms of procedure, which poses a specific set of challenges. Subsequently, it transferred to these institutions Rule 11bis cases, ready to be tried, as well as further evidentiary material, out of which additional cases could be built. These cases and evidentiary material were meant to kick off the work

150 The focus will be on initiatives towards Bosnia and Herzegovina and Serbia, with BiH being the main target of the ICTY's rule of law promotion efforts and Serbia being the least important target. To compare those two countries hence gives an idea about the range of activities and their impact.

151 On advantages of specialized institutions and the Serbian experience, see M. Majić \& D. Ignatović, 'Deset smerica zasnovanih na iskustvu Srbije vezanom za pitanja ratnih zločina', 9 FICHL Policy Brief Series (2012). 
of the specialized institutions, with the help and under supervision of the ICTY Office of the Prosecutor.

In 2002, the State Court of Bosnia and Herzegovina (SCBiH) was set up by a decision of the High Representative (OHR), ${ }^{152}$ the institution responsible for overseeing implementation of civilian aspects of the Dayton Peace Agreement ending the war in Bosnia and Herzegovina. At the same time, ICTY judges recommended the establishment of a specialized war crimes chamber within this court, staffed with both national and international judges. ${ }^{153}$ While until 2005, trials for war-related crimes had been held only in the courts of the entities, the Federation of Bosnia and Herzegovina and the Republika Srpska, the most complex war crimes cases now take place within the new war crimes department at the State Court of BiH. ${ }^{154}$ The corresponding BiH State Prosecutor's Office was established in January 2003, ${ }^{155}$ and since March 2005 it also includes a special department for war crimes. ${ }^{156}$ Overall, local actors report an overwhelming involvement of the ICTY in the establishment of these war crimes institutions in Bosnia and Herzegovina. In fact, the war crimes department was set up upon an agreement between and as a "joint initiative"157 of the OHR and the Tribunal. In addition, ICTY officials performed an important role with regard to the

152 Cf. Office of the High Representative, Decision Establishing the BiH State Court, 12 November 2000; the Law on the Court of Bosnia and Herzegovina had later been adopted by the two chambers of the BiH parliament as well; see: Sud Bosne i Herzegovine, 'Istorijat Suda BiH', supra note 44.

153 Cf. Jorda, 'Report on the Judicial Status of the ICTY', supra note 33, 25.

154 Cf. Y. Ronen, 'The Impact of the ICTY on Atrocity-Related Prosecutions in the Courts of Bosnia and Herzegovina', 3 Penn State Journal of Law and International Affairs (2014) 1, 113, 124; see also: Government of BiH, 'Državna Strategija za Rad na Predmetima Ratnih Zločina' (National War Crimes Strategy), December 2008, 11-12, available at http://www.mpr.gov.ba/web_dokumenti/Drzavna\%20strategije\%20za\%20rad\%20 na\%20predmetima\%20RZ.pdf (last visited 10 December 2018).

155 It was established by the Law on the Prosecutor's Office of Bosnia and Herzegovina, enacted by the High Representative in August 2002, and adopted by the Bosnian parliament in October 2003. The Law is published in the Official Gazette of Bosnia and Herzegovina, No 42/03.

156 Article 12 (3) Law on the Prosecutor's Office of Bosnia and Herzegovina; for more information, see the Prosecution Service's website: http://www.tuzilastvobih.gov. ba/?opcija=sadrzaj\&kat=1\&id=2\&jezik=e (last visited 10 December 2018).

157 United Nations Security Council, 'Security Council Briefed on Establishment of War Crimes Chamber Within State Court of Bosnia and Herzegovina', Press Release, SC/7888, 8 October 2003, available at http://www.un.org/press/en/2003/sc7888.doc. htm (last visited 10 December 2018). 
future work of the new court, ${ }^{158}$ most importantly in preparing the SCBiH for receiving cases from The Hague. ${ }^{159}$ In that regard, the Tribunal not only provided expertise in establishing these institutions, but also exerted pressure as it needed to make sure that there are domestic institutions equipped of receiving Rule 11 bis cases. ${ }^{160}$

In Serbia, only a limited number of war crimes trials had taken place between 1991 and 2003. The serious concerns as to the proper conduct and fairness of these trials ${ }^{161}$ considerably diminished with the establishment of specialized organs within the judicial system in 2003. ${ }^{162}$ With the Law on War Crimes, ${ }^{163}$ specialized institutions - the War Crimes Prosecutor's Office, the War Crimes Department within the Belgrade High Court, and the War Crimes Investigation Service within the Police - were established. ${ }^{164}$ Contrary to the situation in Bosnia and Herzegovina, in Serbia the establishment of specialized institutions were not instigated or brought about directly by the ICTY, but rather by regime change and external coercion. ${ }^{165}$ However, prominent ICTY staff members participated in the expert group that assisted the Serbian government in the drafting of the Law on War Crimes, and their recommendations to establish specialized war crimes institutions were implemented. ${ }^{166}$

158 Cf. Burke-White, 'The Domestic Influence', supra note 63, 336.

159 Cf. ICTY, Completion Strategy Report November 2004, supra note 47, 4.

160 Cf. Burke-White, 'The Domestic Influence', supra note 63, 335-344; interview with a representative of the Office of the High Representative, Sarajevo, 8 February 2017.

161 Cf. OSCE, War Crimes Proceedings in Serbia (2003-2014) - An analysis of the OSCE Mission to Serbia's monitoring results (2015), 21.

162 Cf. K. Michaeli, The Impact of the International Criminal Tribunal for Yugoslavia on War Crime Investigations and Prosecutions in Serbia (2011), 59.

163 The Law on Organization and Competences of Government Authorities in War Crimes Proceedings, Official Gazette of the Republic of Serbia, No 67/2003, and subsequent amendments.

164 For more information on the war crimes prosecution office, see: http://www.tuzilastvorz. org.rs/sr/ (last visited 10 December 2018), and on the war crimes department, see: http:// www.bg.vi.sud.rs/lt/articles/o-visem-sudu/uredjenje/sudska-odeljenja/ (last visited 10 December 2018).

165 Cf. Michaeli, 'The Impact of the ICTY in Serbia', supra note 162, 59; coercion was exerted most notably through the European Union with its conditionality policy. I have elaborated on the EU's conditionality policy elsewhere: K.-H. Brodersen, 'The ICTY's Conditionality Dilemma', 22 European Journal of Crime, Criminal Law and Criminal Justice (2014) 3, 219.

166 Cf. L. Rüedi, War Crimes Trials in Bosnia and Herzegovina: Selected Aspects of Transitional Justice Mechanisms (2015), 86. 
In the following, the ICTY transferred eight Rule 11bis cases involving 13 accused to the countries of the former Yugoslavia: ${ }^{167}$ ten to Bosnia and Herzegovina, two to Croatia, and one to Serbia. ${ }^{168}$ In addition, the Tribunal has provided professional advice on reforming relevant legislation, especially in areas such as command responsibility and witness protection, so that these cases could be properly adjudicated. ${ }^{169}$

The calculation was that Rule 11bis cases would be a "catalyst for the strengthening of competent national judicial systems" 170 and that once they would be completed successfully, prosecutions and trials for international crimes would become the norm. ${ }^{171}$ Opinions about the success of this rule of law promotion initiative are split, with the ICTY viewing it as very positive, ${ }^{172}$ and while in Bosnia and Herzegovina some actors agree, ${ }^{173}$ other are more skeptical. ${ }^{174}$ The ICTY especially emphasized that the threat of taking back the of the ICTY in Serbia', supra note 162,67), only one case was referred to Serbia under Rule 11bis (cf. ICTY, 'Vladimir Kovacevic Declared Unfit to Stand Trial', Press Release, OK/MOW/1069e, 12 April 2006, available at http://www.icty.org/en/press/vladimirkovacevic-declared-unfit-stand-trial (last visited 10 December 2018)). While the Bench declared it was satisfied that the Serbian legal system met the fair trial requirement, the fact that the Kovačević case was the only one referred to Serbia was not a source of pride considering the opposite conclusion reached by the Bench one year prior: in the Mrkšic case (the Vukovar Three case), Serbia's bid for referral was rejected (just as Croatia's) by the Referral Bench on the grounds of fair trial concerns (cf. ICTY, Prosecutor v. Mrksić, Radić, Šljivančanin, 'Decision on Prosecutor's Motion to Withdraw Motion and Request for Referral of Indictment under Rule 11bis', IT-95-13/1-PT, Referral Bench, 30 June 2005). Serbia was also denied referral of the Mejakić case in April 2006, albeit on grounds that $\mathrm{BiH}$ possessed a stronger nexus with the case; cf. ICTY, Prosecutor v. Mejakić, Decision on Joint Defense Appeal against Decision on Referral under Rule 11bis, IT-0265, Referral Bench, 7 April 2006.

Cf. ICTY, 'Completion Strategy', supra note 13.

Ibid.

Interview with a former international prosecutor in the Bosnian State Prosecution, The Hague, 7 December 2016.

Interview with a representative of the ICTY Office of the Prosecutor, The Hague, 25 November 2016; interview with an ICTY judge, The Hague, 2 December 2016.

173 Interview with a former international prosecutor in the Bosnian State Prosecution, The Hague, 7 December 2016; interview with a prosecutor of the Bosnian State Prosecution, Sarajevo, 9 February 2017; interview with a SCBiH judge, Sarajevo, 1 February 2017.

Interview with a Bosnian defense counsel, Sarajevo, 31 January 2017; interview with a representative of an international organization, Sarajevo, 2 February 2017; in particular, 
case if it is not dealt with properly - and the OSCE monitoring would provide proof for that - would have made national actors to be particularly cautious in handling these cases. In addition, Bosnians praise the tailor-made training provided by the OSCE, which directly addressed the needs of the local judiciary, which were observed and assembled in the OSCE's trial monitoring of Rule 11 bis cases. ${ }^{175}$ However, what is for sure is that the international community, the ICTY included, was watching how Bosnia and Herzegovina dealt with the Rule 11 bis referrals. People who were involved at the time claim that everyone was therefore doing their very best to "do it right". ${ }^{176}$

In addition to the referral cases, the OTP transferred evidentiary material to national judiciaries and granted them access to electronic databases and archives. ${ }^{177}$ In the first place, case files were transferred regarding suspects investigated by the OTP but where no indictments were ever issued. Here, national judiciaries were enabled to bring these investigations to a conclusion on the basis of the evidence received from the ICTY and to raise indictments where appropriate. In a second place, several mechanisms in view of collaboration on evidentiary issues were put in place. ${ }^{178}$ Similar to transferring ready-made Rule 11bis cases, these initiatives had the aim of enabling domestic legal actors to

they maintain that too few cases were referred, and the threat to revoke the referral was too unrealistic to actually make a difference.

175 Interview with representatives of an international organization, Sarajevo, 2 February 2017; interview with a SCBiH judge, Sarajevo, 2 February 2017.

176 Interview with a former staff member of the Bosnian State Prosecution, 2 February 2017; interview with a former international prosecutor at the Bosnian State Prosecution, The Hague, 7 December 2017.

177 Cf. ICTY, 'Completion Strategy', supra note 13.

178 For instance, the OTP responds to specific requests from national prosecutors for information relating to their investigations; national liaison prosecutors sent to The Hague by the domestic judiciaries have direct access to the ICTY OTP databases and can directly use the material found there for investigations and prosecutions at national level; the ICTY is producing transcripts of its key proceedings in Bosnian, Croatian and Serbian (BCS) with the aim of improving the ability of national legal practitioners to access and search through testimony given before the ICTY for the purpose of their domestic proceedings; and also the Tribunal's Appeals Chamber Case Law Research Tool, which contains a compilation of summaries of the most important Appeals Chamber decisions, is being translated into BCS. In addition, specially tailored trainings are provided to lawyers in the region in order to assist them in accessing the Tribunal's records; cf. ICTY, Working with the Region, available at http:/www.icty.org/en/about/ office-of-the-prosecutor/working-with-the-region (last visited 10 December 2018); ICTY, Capacity Building, available at http://www.icty.org/en/outreach/capacity-building (last visited 10 December 2018). 
initiate investigations and prosecutions on their own, but still be supported by the ICTY.

\section{Enhancing Competence: Capacity Building}

In light of serious concerns about the state of the judicial systems in the former Yugoslavia, ${ }^{179}$ in particular in terms of independence and competence, the 2002 ICTY completion strategy proposal already entailed recommendations about a number of reforms to be carried out in $\mathrm{BiH}$. In particular, the judges advised incorporating all international crimes into the country's substantive penal law, to strengthen fair trial rights, ${ }^{180}$ to improve detention conditions, to abolish the death penalty, to ensure the independence and impartiality of the judiciary, and to adopt a code of professional conduct for the judiciary. ${ }^{181}$

Despite this early engagement in advice on legal reform, capacity building had not been on the ICTY's priority list for long. Interaction between ICTY judges and their local counterparts was very difficult in the beginning, especially with Serbia. Apart from the political conditions which made such interaction difficult, the mutual mistrust between the judiciaries and the prevailing opinion amongst ICTY judges that this was not part of the mandate of the Tribunal contributed to the professional disconnect between the two systems. ${ }^{182}$ In 2002, David Tolbert, former Senior Legal Adviser to the President of the ICTY, wrote about the ICTY's failure to build domestic legal capacity as "catastrophic" since "outside the relatively small number of accused who have faced or will face trial in The Hague", the local mechanisms "to bring to justice the scores of other perpetrators who committed serious violations of international humanitarian law in the territory of the former Yugoslavia"183 were ineffective. He deplored the irony of the "legacy of the rule of law" 184 that the ICTY would leave behind:

179 Cf. C. Jorda, 'Report on the Judicial Status of the ICTY', supra note 33.

180 In particular that public proceedings must be guaranteed, that the accused must be tried within a reasonable time, that the principle of the presumption of innocence and the equality of arms must be respected and that the victims and witnesses must be duly protected; cf. C. Jorda, 'Report on the Judicial Status of the ICTY', supra note 33, 25.

181 Cf. C. Jorda, 'Report on the Judicial Status of the ICTY', supra note 33, 18, 25.

182 Cf. Michaeli, 'The Impact of the ICTY in Serbia', supra note 162, 49-50.

183 D. Tolbert, 'The International Criminal Tribunal for the Former Yugoslavia: unforeseen Success and Foreseeable Shortcomings', 26 The Fletcher Forum of World Affairs (2002) 2, 7, 12 .

184 V. Hussain, 'Sustaining Judicial Rescues: The Role of Outreach and Capacity Building Efforts in War Crimes Tribunals', 45 Virginia Journal of International Law (2005) 2, 547 , 562. 
despite the millions spent on building a judicial infrastructure in The Hague, virtually no effective enforcement of these laws persisted in the courts that ultimately matter most: the region's domestic courts. ${ }^{185}$

As late as 2008, there was a shift in thinking with the Tribunal beginning to develop a program on its legacy which put special emphasis on enhancing the capacity of domestic systems in the region. Consequently, the Tribunal intensified the interaction with the local judiciaries, studied their needs and responded to them directly. ${ }^{186}$ Today, the ICTY describes supporting legal professionals and institutions in the region as a "key aspect of the Tribunal's work"187. Since 2010, the ICTY Outreach Program is responsible for capacity building by organizing working visits, training seminars, workshops and other activities, in order for the Tribunal to transfer its expertise to local counterparts in a wide range of areas, ranging from legal jurisprudence to courtroom techniques and witness protection. ${ }^{188}$

Although over the years the ICTY managed to cultivate a positive working relationship with Serbian institutions entrusted with war crimes prosecutions, ${ }^{189}$ contact between the ICTY and the Bosnian judiciary was much more regular and intensive than with actors from the Serbian judiciary. ${ }^{190}$ Amongst other reasons, this was due to the fact that most Rule 11bis cases had been referred to $\mathrm{BiH}$ and the ICTY consequently geared its capacity building efforts towards that country in order to address the shortcomings within the institutional dimension of the rule of law that were observed in the course of these local trials. In $\mathrm{BiH}$, one can also observe greater impact: ${ }^{191}$ for instance, the State Court of Bosnia and Herzegovina regularly uses ICTY case law concerning the interpretation of Michaeli, 'The Impact of the ICTY in Serbia', supra note 162, 57; an overview on the activities can be found under ICTY, Overview of Capacity Building Activities, available at http://www.icty.org/en/outreach/capacity-building/overview-activities (last visited 10 December 2018).

187 ICTY, Capacity Building, supra note 178.

188 Cf. ICTY, Overview of Capacity Building Activities, supra note 186.

189 Cf. Michaeli, 'The Impact of the ICTY in Serbia', supra note 162, 5.

190 See, amongst others, the project's calendar of activities under OSCE, War Crimes Justice Project-Calender of Activities, available at http://www.icty.org/x/file/Outreach/capacity_ building/wcjp_activity_calendar.pdf (last visited 10 December 2018).

191 For a critical review of capacity building initiatives in $\mathrm{BiH}$, see A. Chehtman, 'Developing Bosnia and Herzegovina's Capacity to Process War Crimes Cases: Critical Notes on a 'Success Story', 9 Journal of International Criminal Justice (2011) 3, 547. 
different international crimes or modes of liability, or in order to fill gaps in their criminal procedure. ${ }^{192}$

\section{Raising Awareness in order to Build a Culture of Law: Outreach Program}

As mentioned in section D.II. above, the beginning of the Tribunal's work was marked by a virtual absence of contact between the local judiciaries and actors in The Hague. Likewise, in its early years, the ICTY was reluctant to communicate with the citizens of the former Yugoslavia about the objectives and goals of the Tribunal. ${ }^{193}$ Consequently, in the region, people sensed that the primary audience for the ICTY was the international community, that it mainly sought to further develop international humanitarian, human rights, and criminal law, and that it was rather an enforcer of the international rule of law, ${ }^{194}$ than contributing to the national rule of law. It was viewed as remote and disconnected from the population. That there was little information available about and from the ICTY (at least in local languages) was frequently used and abused for propaganda purposes by its opponents. And indeed, only when the ICTY realized how poorly it was perceived in the region and that this negative perception impacted its work, it began thinking about communicating with the local audience. ${ }^{195}$ ICTY President Gabrielle Kirk McDonald then initiated the Outreach Program in 1999, six years into the Tribunal's existence. In hindsight, it is described as "a milestone in the Tribunal's progression to maturity"196

192 I have elaborated on this elsewhere: K.-H. Brodersen, "We learnt that from The Hague” - How the ICTY influenced the fairness of criminal trials in the former Yugoslavia', in C. Stahn et. al. (eds.), Legacies of the International Criminal Tribunal for the Former Yugoslavia: A Multidisciplinary Account (forthcoming 2019); while local actors both in Bosnia and Herzegovina as well as in Serbia appreciate the close collaboration with the ICTY, they do insist that initiatives from other partners, such as the OSCE, were more useful; interviews with national prosecutors (Belgrade, 19 January 2017 and Sarajevo, 9 February 2017).

193 Cf. N. H. Pentelovitch, 'Seeing Justice Done: The Importance of Prioritizing Outreach Efforts at International Criminal Tribunals', 39 Georgetown Journal of International Law (2007) 3, 445, 451.

194 Cf. Hussain, 'Sustaining Judicial Rescues', supra note 184, 561-562.

195 Cf. S. Darehshori, 'Lessons for Outreach from the Ad Hoc Tribunals, the Special Court for Sierra Leone, and the International Criminal Court', 14 New England Journal of International and Comparative Law (2007) 2, 299, 301.

196 ICTY, Outreach Programme, available at http://www.icty.org/en/outreach/outreachprogramme (last visited 10 December 2018). 
and "a sign that the court had become deeply aware that its work would resonate far beyond the judicial mandate of deciding the guilt or innocence of individual accused." 197 With the establishment of Outreach, the Tribunal had recognized that it had a role to play in the process of dealing with the past in the former Yugoslavia, and that it could contribute to raising awareness about the accountability proceedings taking place in The Hague, and to spreading the truth that had been found in the course of these proceedings.

The Outreach Program was therefore effectively designed as a massive public relations and information spreading initiative. It consisted of several components, with particular emphasis on reaching out to the youth. ${ }^{198}$ The first, and arguably the most important, step was to regularly translate ICTY materials into BCS, including the website. Also, live broadcasting of the proceedings on the internet commenced. Since 2000, offices had been opened in Belgrade, Pristina, Sarajevo and Zagreb, responsible for communicating with the media, the political, and the legal community, governmental and non-governmental organizations, universities and high schools, victims associations, and diplomatic representatives. ${ }^{199}$ According to the ICTY, thousands of people came into direct contact with the Tribunal through a variety of activities every year. These activities included work with the younger generation, grassroots communities, and the media; visits to the ICTY; and the production of a variety of information materials, multi-media website features, and social media outputs. ${ }^{200}$ At least as of the moment that all fugitives had been arrested in 2011, the Tribunal yet again enhanced and methodologically revised its outreach efforts, as it saw the "definitive opportunity to work with the communities in the region to reflect on the Tribunal's achievements and carry that legacy forward." 201

Arguably, although many observers feel that the effort was too limited in scope and came too late to have any real effect, ${ }^{202}$ through its outreach program

197 Ibid.

198 For Youth Outreach, see http://www.icty.org/en/outreach/youth-outreach; for a list of activities, see http://www.icty.org/en/outreach/activities-archive; for the annual reports, see http://www.icty.org/en/outreach/outreach-annual-reports (all last visited 10 December 2018).

199 At the time of writing, only the offices in Belgrade and Sarajevo were still operating.

200 Cf. ICTY, 'Outreach Programme', supra note 196.

201 Ibid.

202 Cf. Hussain, 'Sustaining Judicial Rescues', supra note 184, 563; Tolbert, 'Unforeseen Success and Foreseeable Shortcomings', supra note 183, 14. 
the ICTY contributed to "shrinking the space for denial"203 in the former Yugoslavia, which is the basis for a culture of law - the cultural dimension of the rule of law. In addition, thanks to lessons learned from the ICTY, outreach has now become a key component of international criminal justice. ${ }^{204}$ Many of its initiatives, especially accessible publications on the prosecutors' investigations, the courts' trial work and their procedures, as well as outreach to the youth has been taken up in Bosnia and Herzegovina, and even Serbia. ${ }^{205}$

\section{E. Conclusion}

The goal of the research this contribution is based on was to shed light on what made the ICTY engage in a promotion of the rule of law, what the ICTY understood by the 'rule of law', and how this understanding influenced its - very indirect - rule of law promotion efforts. The analysis presented here permits several conclusions.

First, the discourse and document analyses reveal that the ICTY's notion of the rule of law changed over time. Very early and very late references highlighted its role in promoting what has been termed the international rule of law. In between, the national rule of law was much more prominent in the ICTY's discourse. Clearly, this shift in notions reflects the changing standing of the ICTY over time: in its early and late years it sought to justify its existence and underline its achievements and it did so by emphasizing its role as the enforcer of universal international criminal and humanitarian law. Around the 2000s and beyond, the completion strategy required the Tribunal to rethink its role, in particular because it realized that the domestic justice systems in the former Yugoslavia needed assistance in preparing for receiving Rule 11bis cases from The Hague. What followed was a range of measures aimed at contributing to the consolidation of the domestic justice systems in the region, which effectively rendered Rule 11bis the legal mechanism the ICTY's rule of law promotion efforts were rooted in.

A phrase that became prominent with the book of Orentlicher, Shrinking the Space for Denial, supra note 5.

204 Cf. Darehshori, 'Lessons for Outreach', supra note 195, 299.

205 Interviews with national prosecutors (Belgrade, 19 January 2017 and Sarajevo, 9 February 2017); although it should be noted that while the SCBiH publishes all its decisions and judgments online, the war crimes chamber at the Belgrade High Court has a very restrictive policy towards access to court materials: they are not available online and one must ask for permission to access them, which is given only concerning particularly mentioned judgments, which makes a comprehensive search impossible. 
The analysis further reveals that the 'national rule of law' as understood by the ICTY has a normative dimension, an institutional dimension, and a cultural dimension. In the normative dimension, emphasis was put on the necessity of a legislative framework that foresees the adjudication of international crimes and guarantees certain fundamental human rights, especially fair trial rights. This is the law that should rule. The institutional components of a justice system that ensure that it actually operates under the rule of law comprise independent and impartial judicial organs that work efficiently and in a fair, non-discriminatory, and transparent manner. Lastly, the ICTY recognized that a culture of law is paramount and that ordinary citizens, as well as public officials, and representatives of the judicial sector adopt an ideology of legality.

A third revelation is that within the ICTY's notion of the 'national rule of law', its emphasis on different elements also changed over time. Mostly, this reflected the current challenges the Tribunal or the countries of the former Yugoslavia faced at the respective time. Interestingly, the Tribunal reacted to these events and adapted its rule of law promotion efforts accordingly. For instance, in the early 2000s emphasis was placed on the necessity to conduct national war crimes proceedings and to conduct them fairly and without discrimination. This related to the normative dimension of the Tribunal's rule of law conception. It hence started to actively lobby and advise on the setting up of specialised domestic institutions that would deal with international crimes, and facilitated their start by transferring ready-made cases and other material. As of 2008, when the ICTY reflected upon the legacy it would leave behind, it enhanced its capacity building to strengthen domestic competence and efficiency to prosecute and adjudicate international crimes cases, as this was determined to be one of the major obstacles to successful international crimes trials in the former Yugoslavia. These initiatives sought to consolidate the institutional dimension of the rule of law. Around the same time, bearing in mind its impending closure, the ICTY called upon national judiciaries to raise awareness of international crimes trials such that the local population would develop trust that impunity is no longer accepted. It was hoped that this would strengthen the culture of law - the cultural dimension of the rule of law. In order to contribute to this awareness raising and to serve as an example for similar local initiatives, the Tribunal rendered its Outreach Program more robust.

It has been shown that the ICTY engaged in rule of law promotion on the basis of its completion strategy and, in particular, Rule 11bis of its Rules of Procedure and Evidence. Although these initiatives were not based on an explicitly expressed definition of the rule of law, a mosaic of elements the Tribunal associated with this concept emerges from its case law and public 
statements. It was demonstrated that the Tribunal's rule of law promotion efforts directly related to this rule of law conception. This piece, therefore, contributes to understanding the legal and normative bases of the ICTY's rule of law strengthening efforts in the post-conflict former Yugoslavia. 